\title{
KANONSKO PRAVO I HRVATSKI PRAVNI SUSTAV (II) CODEX IURIS CANONICI I SUVREMENO HRVATSKO PRAVO
}

Četiri međunarodna ugovora sklopljena izmedu Svete Stolice i Republike Hrvatske kao nadzakonski akti, a posebice Ugovor između Svete Stolice i Republike Hrvatske o pravnim pitanjima, u znatno se vé́oj mjeri referiraju na kanonsko pravo (ius canonicum) kao pravni sustav mjerodavan za uređenje pojedinih pravnih odnosa nego što je to slučaj s tuzemnim ugovorima između Vlade Republike Hrvatske i pojedinih vjerskih zajednica. Štoviše, već u samom uvodu spomenutog ugovora navodi se i kanonsko pravo kao jedan od njegovih pravnih temelja. Sami tekstovi spomenutih ugovora govore o "kanonskom pravu", "crkvenom zakonodavstvu", "crkvenim zakonima" ili "crkvenim propisima", odnosno pojedinim institutima kanonskog prava ("kanonska ženidba", "kanonske kaznene mjere", "kanonski mandat"). Sukladno navedenim činjenicama, autor istražuje u kojoj mjeri Zakonik kanonskog prava (Codex Iuris Canonici, CIC) iz 1983., ta nedvojbeno najvažnija religijska pravna kodifikacija u svjetskim razmjerima, predstavlja kao cjelina relevantan konceptualni i normativni zajednički okvir za sve odredbe spomenutih medunarodnih ugovora koje se pozivaju na kanonsko pravo ili na pojedine njegove institute. Slijedeci sustav CIC-a po pojedinim knjigama, autor raščlanjuje pojedinačne odredbe navedenih medunarodnih ugovora koje su uvele u hrvatski pravni sustav čitav niz instituta kanonskog prava kao normativno relevantan. Pri tome se upućuje i na temeljnu hrvatsku kanonističku literaturu o

* Dr. sc. Marko Petrak, profesor Pravnog fakulteta Sveučilišta u Zagrebu, Trg Republike Hrvatske 14, 10000 Zagreb; marko.petrak@pravo.hr;

ORCID ID: orcid.org/0000-0003-0920-8361 
problematici koja će se prikazati te se posebice istražuje postojeća praksa hrvatskih državnih sudova glede primjene pojedinih kanona CIC-a, ističući kako dobre primjere takve primjene odredaba kanonskog prava, tako i kritički raščlanjujući pojedine slučajeve u kojima sudovi nisu ponajbolje shvatili te primijenili pojedine aspekte kanonskog prava.

Ključne riječi: kanonsko pravo, hrvatsko pravo, Codex iuris canonici, konkordatsko pravo, međunarodni ugovori, sudska praksa

\section{UVODNE NAPOMENE**}

Četiri međunarodna ugovora sklopljena između Svete Stolice i Republike Hrvatske kao nadzakonski akti ${ }^{1}$, a posebice Ugovor između Svete Stolice i Republike Hrvatske o pravnim pitanjima, u znatno se većoj mjeri referiraju na kanonsko pravo (ius canonicum) kao pravni sustav mjerodavan za uređenje pojedinih pravnih odnosa nego što je to slučaj s tuzemnim ugovorima između Vlade Republike Hrvatske i pojedinih vjerskih zajednica. Štoviše, već u samom uvodu spomenutog ugovora navodi se i kanonsko pravo kao jedan od njegovih pravnih temelja. ${ }^{2}$ Sami tekstovi spomenutih ugovora govore o "kanonskom

** Rad je nastao i zahvaljujući višegodišnjim potporama Sveučilišta u Zagrebu istraživanjima pod naslovom Rimskokanonska pravna tradicija $i$ europeizacija hrvatskog prava (2015. - 2019.), kojeg je autor bio voditelj.

1 Ugovor između Svete Stolice i Republike Hrvatske o pravnim pitanjima; Ugovor između Svete Stolice i Republike Hrvatske o suradnji na području odgoja i kulture; Ugovor između Svete Stolice i Republike Hrvatske o dušobrižništvu katoličkih vjernika, pripadnika oružanih snaga i redarstvenih službi Republike Hrvatske; Ugovor između Svete Stolice i Republike Hrvatske o gospodarskim pitanjima; detaljno o nastanku, sadržaju i značenju navedenih međunarodnih ugovora između Svete Stolice i Republike Hrvatske u komparativnom kontekstu vidi u: Eterović, N., Ugovori između Svete Stolice i Republike Hrvatske (povijest nastanka i komentar), Zagreb, 2001., str. $1-402$.

2 Tekst relevantnog dijela uvoda Ugovora između Svete Stolice i Republike Hrvatske o pravnim pitanjima glasi: "Sveta Stolica i Republika Hrvatska, nastojeći odrediti pravni okvir odnosa između Katoličke Crkve i Hrvatske Države, temeljeći se Republika Hrvatska na odredbama Ustava, posebno na člancima 40. i 41. o vjerskoj slobodi i o slobodi savjesti, a Sveta Stolica na dokumentima Drugoga vatikanskog sabora i na odredbama kanonskoga prava ... dogovorili su se o slijedećem..."; vrlo slične formulacije o kanonskom pravu kao jednom od temelja ugovora nalaze se i u uvodu Ugovora između Svete Stolice i Republike Hrvatske o suradnji na području odgoja i kulture te Ugovora između Svete Stolice i Republike Hrvatske o gospodarskim pitanjima; o značenju kanonskog prava kao temelja navedenih međunarodnih ugovora vidi ukratko Eterović, op. cit. u bilj. 1, str. 136 - 137. 
pravu", "crkvenom zakonodavstvu"4, "crkvenim zakonima"5 ili "crkvenim propisima"6, odnosno pojedinim institutima kanonskog prava ("kanonska ženidba"7, "kanonske kaznene mjere", "kanonski mandat") naspram "zakonodavstva Republike Hrvatske", "zakonskim odredbama”, "zakona Republike Hrvatske”ı, "državnog zakonodavstva"11 ili "državnih propisa"12, odnosno pojedinih aspekata državnog prava (npr. "građanski učinci"13, "građanska prava i obveze"14, “civilne zapreke"15).

3 Ugovor između Svete Stolice i Republike Hrvatske o pravnim pitanjima, čl. 2. st. 2.3.; čl. 6. st. 1.; čl. 10. st. 1.; usp. Ugovor između Svete Stolice i Republike Hrvatske o gospodarskim pitanjima, čl. 1. st. 1.; Ugovor između Svete Stolice i Republike Hrvatske o dušobrižništvu katoličkih vjernika, pripadnika oružanih snaga i redarstvenih službi Republike Hrvatske, čl. 1. st. 2.; čl. 3.; čl. 4. st. 2.; čl. 5.; čl. 6. st. 2.; Ugovor između Svete Stolice i Republike Hrvatske o suradnji na području odgoja i kulture, čl. 8. st. 1.; čl. 11. st. 1 .

4 Ugovor između Svete Stolice i Republike Hrvatske o suradnji na području odgoja i kulture, čl. 7. st. 1 .

5 Ugovor između Svete Stolice i Republike Hrvatske o suradnji na području odgoja i kulture, čl. 7. st. 2.; čl. 12. st. 2.

6 Ugovor između Svete Stolice i Republike Hrvatske o gospodarskim pitanjima, čl. 8. st. 2 .

7 Ugovor između Svete Stolice i Republike Hrvatske o pravnim pitanjima, čl. 13.

8 Ugovor između Svete Stolice i Republike Hrvatske o dušobrižništvu katoličkih vjernika, pripadnika oružanih snaga i redarstvenih službi Republike Hrvatske, čl. 6. st. 3.

9 Ugovor između Svete Stolice i Republike Hrvatske o suradnji na području odgoja i kulture, čl. 3. st. 2.

10 Ugovor između Svete Stolice i Republike Hrvatske o pravnim pitanjima, čl. 10.; čl. 11. st. 1; čl. 12. st. 2.; čl. 13.; čl. 14. st. 1.; čl. 15.; čl. 17. st. 5.; Ugovor između Svete Stolice i Republike Hrvatske o gospodarskim pitanjima, čl. 2. st. 1.; čl. 3. st. 1.; čl. 4. st. 1.; čl. 5. st. 2.; čl. 6. st. 1.; čl. 7. st. 2.; Ugovor između Svete Stolice i Republike Hrvatske o suradnji na području odgoja i kulture, čl. 3. st. 1.; čl. 7.; čl. 8.; čl. 9.; čl. 10. st. 1.; čl. 11. st. 1 i 2.; čl. 12. st. 2.

11 Ugovor između Svete Stolice i Republike Hrvatske o suradnji na području odgoja i kulture, čl. 7. st. 1 .

12 Ugovor između Svete Stolice i Republike Hrvatske o pravnim pitanjima, čl. 2. st. 3.; Ugovor između Svete Stolice i Republike Hrvatske o gospodarskim pitanjima, čl. 8. st. 2 .

13 Ugovor između Svete Stolice i Republike Hrvatske o pravnim pitanjima, čl. 10. st. 2.; čl. 13.; čl. 14. st. 1.; čl. 17. st. 5.

14 Ugovor između Svete Stolice i Republike Hrvatske o gospodarskim pitanjima, čl. 8. st. 2.

15 Ugovor između Svete Stolice i Republike Hrvatske o pravnim pitanjima, čl. 13. st. 1. 
Bez obzira na navedenu zasebnost i različitost kanonskog prava s jedne strane te civilnog prava (svjetovnog prava) s druge strane, navedena dva pravna sustava međusobno se prožimaju i isprepleću na različite načine. Tako, primjerice, kanonsko pravo preuzima u pogledu određenih pravnih materija civilne zakone koji su na snazi u kanonskopravni poredak. Kako je opće poznato u kanonističkoj znanosti, riječ je o načinu normiranja koji se naziva "kanonizacija civilnih zakona" (canonizatio legum civilium). Pretpostavke i granice kanonizacije civilnih zakona preciznije definira Zakonik kanonskog prava (Codex Iuris Canonici) iz 1983. (dalje u tekstu: CIC), kan. 22., koji određuje da se "civilni (svjetovni) zakoni, na koje upućuje crkveno pravo ... u kanonskom pravu obdržavaju s jednakim učincima, ako nisu protivni božanskom pravu i ako kanonsko pravo ne određuje nešto drugo". ${ }^{16}$ Možda se najpoznatiji takav primjer "kanonizacije civilnih zakona" nalazi u CIC-u, kan. 1290., koji pod određenim uvjetima predviđa kanonizaciju svjetovnog ugovornog prava određene države: "Ono što civilno pravo na nekom području određuje o ugovorima, bilo općenito bilo posebno, i o njihovu ispunjenju, neka se s istim učincima obdržava u kanonskom pravu u stvarima koje podliježu crkvenoj vlasti upravljanja, osim ako se to protivi božanskom pravu ili ako nešto drugo određuje kanonsko pravo..."17

Za razliku od kanonizacije civilnih zakona, drugi mogući način međusobnog prožimanja i isprepletanja kanonskog prava i civilnog prava jest prihvaćanje kanonskog prava kao izvora važećeg civilnog prava glede određenih pravnih materija. Navedeni fenomen "civilifikacije" kanonskog prava dobio je odavno svoj latinski naziv: ius canonicum in iure civili ("kanonsko pravo u civilnom pravu"). ${ }^{18}$ Polazeći od navedenih činjenica, u ovom ćemo se radu usredotočiti na problematiku kanonskog prava Katoličke Crkve kao izvora prava u hrvatskom

16 Can. 22: Leges civiles ad quas ius Ecclesiae remittit, in iure canonico iisdem cum effectibus serventur, quatenus iuri divino non sint contrariae et nisi aliud iure canonico caveatur; općenito o kanonizaciji civilnih zakona vidi npr. Brkan, J., Opće odredbe Zakonika kanonskog prava, Makarska, 1997., str. 82 - 83; Škalabrin, N., Ugovori i napose otuđenje (kann. 1290-1298), Bogoslovska smotra, vol. 76, br. 1, 2006., str. 174 - 177, s uputama na daljnju inozemnu literaturu.

17 Can. 1290: Quae ius civile in territorio statuit de contractibus tam in genere, quam in specie et de solutionibus, eadem iure canonico quoad res potestati regiminis Ecclesiae subiectas iisdem cum effectibus serventur, nisi iuri divino contraria sint aut aliud iure canonico caveatur, et firmo iure canonico caveatur...; o navedenom kanonu kojim se kanonizira svjetovno ugovorno pravo vidi detaljnije u: Brkan, J., Ugovori i napose otuđenje (kan. 1290-1298), Služba Božja, vol. 45, br. 2, 2004., str. 12 - 16; Škalabrin, op. cit. u bilj. 16, str. 173 - 177.

18 O navedenoj problematici vidi detaljnije npr. u: Wolter, U., Ius canonicum in iure civili. Studien zur Rechtsquellenlehre in der neueren Privatrechtsgeschichte, Köln/Wien, 1975. 
pravnom sustavu na temelju odredaba četiriju međunarodnih ugovora između Svete Stolice i Republike Hrvatske.

Cjelina navedenih međunarodnih ugovora između Svete Stolice i Republike Hrvatske tvori zasebnu pravnu granu u kontekstu hrvatskog pravnog sustava: konkordatsko pravo (ius concordatarium). Kako je već istaknuto u doktrini, "to je pravo redovito nepoznato drugim Crkvama i vjerskim zajednicama, iako i one mogu sklopiti slične sporazume s državnim vlastima koji međutim nemaju međunarodno obilježje". ${ }^{19}$ Još detaljnije rečeno, "ugovori predstavljaju izraz usklađivanja dvaju pravnih sustava, crkvenoga i državnoga, a spadaju u konkordatsko pravo koje je plod dugoga i posebnoga povijesnog nastojanja i iskustva odnosa Katoličke Crkve s državama i njezine prisutnosti u različitim narodima svijeta. Ugovori nadalje daju hrvatskom pravu novi doprinos i otvaraju novo područje suradnje između kanonskoga i građanskoga prava." 20

Imajući u vidu, kako je već istaknuto, da su upravo "odredbe kanonskog prava" explicite navedene kao jedan od samih fundamenata međunarodnih ugovora između Svete Stolice i Republike Hrvatske, potrebno je utvrditi na koje se pravne izvore spomenuta sintagma "odredbe kanonskog prava" točno odnosi. U tom kontekstu dostatno je navesti da je u doktrini već precizno i jezgrovito istaknuto da se u uvodima tih međunarodnih ugovora "izrazom odredbe kanonskog prava podrazumijevaju odredbe Zakonika kanonskog prava i Zakonika kanona istočnih crkava te sve druge odredbe Katoličke Crkve koje imaju snagu zakona, bilo opće, koje vrijede za cijelu Katoličku Crkvu, bilo posebne, kao na primjer, odredbe Hrvatske biskupske konferencije koje vrijede za Katoličku Crkvu u Republici Hrvatskoj". ${ }^{21}$

Sukladno navedenom shvaćanju, daleko najvažniji izvori kanonskog prava u hrvatskom kontekstu jesu Zakonik kanonskog prava (Codex Iuris Canonici) iz 1983. kao zakonik latinske Crkve te Zakonik kanona istočnih Crkava (Codex Canonum Ecclesiarum Orientalium) iz 1990. (dalje u tekstu: CCEO) kao zakonik istočnih katoličkih crkava, pripadnim obredima (ritus) aleksandrijske, antiohijske, armenske, kaldejske i carigradske predaje. Oba ta velika zakonika kanonskog prava, proglašena u doba pontifikata sv. Ivana Pavla II., objavljena su i u Hrvatskoj u svojim izvornicima na latinskom jeziku uz usporedni hrvatski

19 Cit. Eterović, N., Ugovori između Svete Stolice i Republike Hrvatske, Crkva u svijetu, vol. 32, br. 2, 1997., str. 184.

20 Cit. Bozanić, J., Predgovor, u: Eterović, op. cit. u bilj. 1, str. 6; usporedi i Zec, S., Pravni temelji prisutnosti i djelovanja Crkve u javnosti u Republici Hrvatskoj, Riječki teološki časopis, vol. 36, br. 2, 2011 ., str. $397-399$.

21 Cit. Eterović, op. cit. u bilj. 1, str. 137. 
prijevod. ${ }^{22} \mathrm{U}$ navedenom kontekstu svakako je potrebno spomenuti i Zakonik kanonskog prava (Codex Iuris Canonici) iz 1917. (dalje u tekstu: CIC 1917) - inače također nedavno objavljen u nas na latinskom jeziku uz usporedni hrvatski prijevod - kao prvu kodifikaciju kanonskog prava latinske Crkve te neposrednog preteču CIC-a iz 1983., koji u mnogim aspektima i u suvremenosti omogućuje temeljitije i cjelovitije shvaćanje kanona danas važećeg Zakonika. ${ }^{23}$

U navedenom kontekstu potrebno je posebice istaknuti da na području Republike Hrvatske više od 99 \% katolika pripada Crkvi latinskog obreda, dok od "nelatinskih" struktura postoji jedino grkokatolička Križevačka eparhija, koja - usprkos tome što obuhvaća manje od 1 \% katolika u Hrvatskoj - ima status samosvojne Crkve (sui iuris) bizantsko-slavenskog obreda nastalog iz carigradske predaje (traditio Constantinopolitana). ${ }^{24}$ Budući da Crkvi latinskog obreda pripada i oko 98,6 \% od oko milijardu i tristo milijuna katolika u svijetu, Codex Iuris Canonici nedvojbeno je najvažnija religijska pravna kodifikacija u svjetskim razmjerima. Stoga će razumljivom biti činjenica - kako lokalno, tako i globalno - da ćemo se i u nastavku ove raščlambe $\mathrm{u}$ pravilu usredotočiti na kanone navedenog Zakonika. ${ }^{25}$

22 Codex Iuris Canonici fontium annotatione auctus / Zakonik kanonskog prava s izvorima, Zagreb, 1996.; Codex Canonum Ecclesiarum Orientalium fontium annotatione auctus / Zakonik kanona istočnih Crkava s izvorima, Zagreb, 1996. O istovjetnostima i razlikama između tih dvaju kanonskih zakonika u hrvatskom kontekstu već je pisano u našoj kanonističkoj znanosti te stoga upućujemo na ta vrijedna istraživanja; vidi Brkan, J., Neke razlike u Zakonicima latinske Crkve i istočnih katoličkih crkava, Služba Božja, vol. 54, br. 1, 2014., str. 5 - 34. Također treba istaknuti i da je objavljen Usporedni popis kanona CIC i CCEO uz pomoć kojega je moguće na jednostavan način pronaći podudarne i usporedive kanone dvaju zakonika. Njega je priredio je Matija Berljak, dugogodišnji predstojnik Katedre kanonskog prava Katoličkog bogoslovnog fakulteta Sveučilišta u Zagrebu, a objavljen je u: Codex Iuris Canonici fontium..., op. cit., str. 1086 - 1121.

23 Codex Iuris Canonici iz 1917. nedavno je izdan u Hrvatskoj čak u dvama prijevodima, izrađenima još u prvoj polovici 20. st. (Josip Pazman, Franjo Herman), koji prethodno nisu objavljeni: Codex Iuris Canonici fontium annotatione auctus MDCCCCXVII / Kodeks kanonskog prava s izvorima 1917. (preveo Franjo Herman), Zagreb, 2007.; Berljak, M., Zakonik crkvenog prava, uređen po odredbi pape Pija X., proglašen po nalogu pape Benedikta XV. (1917.). Dr. Josip Pazman (1863. - 1925.), Zagreb/Rim, 2014. Također treba istaknuti da je u nas objavljen i Usporedni popis kanona CIC-a iz 1983. i CIC-a iz 1917., koji je također priredio Matija Berljak, a objavljen je u Codex Iuris Canonici fontium..., op. cit. u bilj. 22, str. 1122 - 1162.

24 O povijesti Križevačke eparhije vidi npr. Ivanišević, G., Marčanska unija 1611. i Križevačka eparhija 1777. Ljetopis i pojmovnik, Zagreb, 2018., uz iscrpnu bibliografiju.

25 Problematika sadržana u uvodnom poglavlju ovog rada već je detaljnije, u drugom kontekstu, izložena u: Petrak, M., Kanonsko pravo i hrvatski pravni sustav (I). Pravni izvori i pravna načela, Zbornik Pravnog fakulteta u Zagrebu, vol. 70, br. 2-3, 2020., str. $251-286$. 


\section{CODEX IURIS CANONICI I SUVREMENO HRVATSKO PRAVO}

Već smo na samom početku rada istaknuli kako je kanonsko pravo jedan od pravnih temelja četiriju međunarodnih ugovora između Svete Stolice i Republike Hrvatske te okvirno naveli norme tih ugovora u kojima se referira na kanonsko pravo kao relevantan normativni sadržaj. Na temelju navedenih prethodnih napomena u nastavku ćemo sažeto nastojati obraditi problematiku kanonskog prava kao izvora prava u hrvatskom pravnom sustavu na temelju odredaba spomenutih međunarodnih ugovora kao konkordatskog prava. Pri tome ćemo se, što se kanonskog prava tiče, ograničiti iz upravo objašnjenih razloga na njegov najvažniji izvor: Zakonik kanonskog prava (Codex Iuris Canonici) iz 1983.

CIC se kao sustavna cjelina sastoji od sedam knjiga pod sljedećim naslovima: I. Opće odredbe (De normis generalibus) (kann. I - 203); II. Božji narod (De populo Dei) (kann. 204-746); III. Naučiteljska služba Crkve (De Ecclesiae munere docendi) (kann. 747 - 833); IV. Posvetiteljska služba Crkve (De Ecclesiae munere sanctificandi) (kann. 834-1253); V. Vremenita crkvena dobra (De bonis Ecclesiae temporalibus) (kann. 1254-1310); VI. Kaznene mjere u Crkvi (De sanctionibus in Ecclesia) (kann. 1311 - 1399); VII. Postupci (De processibus) (kann. 1400 - 1752). ${ }^{26}$

Kada se temeljitije raščlane pojedine odredbe međunarodnih ugovora između Svete Stolice i Republike Hrvatske, neće biti teško zaključiti da je zapravo na temelju navedenih odredbi CIC kao cjelina postao relevantni izvor prava $\mathrm{u}$ hrvatskom pravnom sustavu.

U nastavku teksta, slijedeći sustav CIC-a po pojedinim knjigama, istaknut ćemo pojedinačne odredbe navedenih međunarodnih ugovora koje su uvele $\mathrm{u}$ hrvatski pravni sustav čitav niz instituta kanonskog prava kao normativno relevantan. Pri tome ćemo uputiti i na temeljnu relevantnu hrvatsku kanonističku literaturu o problematici koja će se prikazati te pregledno ukazati na postojeću praksu hrvatskih državnih sudova glede pojedinih kanona CIC-a.

I knjiga CIC-a pod naslovom Opće odredbe (De normis generalibus) (kann. l -203), kao svojevrsni kanonski analogon općem dijelu civilnih kodifikacija, sadržava

26 O nastanku, sustavu, temeljnim obilježjima i značenju CIC-a vidi npr. Berljak, M., Novi crkveni Zakonik - Kodeks kanonskoga prava Ivana Pavla II. - Nastajanje - proglašenje - stupanje na snagu - sadržaj, Bogoslovska smotra, vol. 53, br. 2-3, 1983., str. 165 182; Manjgotić, J., Temeljne postavke i ustroj novog Zakonika, Svesci - Časopis Centra za koncilska istraživanja, dokumentaciju i informacije "Kršćanska sadašnjost”, vol. 14, br. 51, 1983., str. 17 - 24; Berljak, M., Iter i glavne značajke novog Kodeksa kanonskog prava, Bogoslovska smotra, vol. 54, br. 2-3, 1984., str. 234 - 254; Šalković, J., Zakonik kanonskog prava - teološko-pravna sinteza Sabora, Bogoslovska smotra, vol. 75, br. 3, 2005., str. 767 - 792, s uputama na daljnju literaturu. 
načela, institute i pojedine odredbe koje su zajedničke svim ostalim knjigama CIC-a, odnosno svim pravnim materijama koje taj Codex uređuje. Primjerice, nakon općih odredaba o izvorima kanonskog prava (crkveni zakoni, običaj, opće odluke, pojedinačni upravni akti, statuti i pravilnici), navedena knjiga regulira materiju fizičkih i pravnih osoba, pravnih čina, vlasti upravljanja, crkvenih službi te naposljetku pitanja zastare i računanja vremena. Osim toga što je I. knjiga CIC-a relevantni konceptualni i normativni zajednički okvir za sve odredbe međunarodnih ugovora između Svete Stolice i Republike Hrvatske koje se pozivaju na kanonsko pravo ili na pojedine njegove institute, navedena knjiga Zakonika najizravnije je, primjerice glede materije pravnih osoba, relevantna za adekvatno tumačenje i primjenu čl. 2. st. 2. - 3. Ugovora o pravnim pitanjima, koji određuju da Republika Hrvatska priznaje javnu pravnu osobnost svih crkvenih ustanova, koje imaju takvu pravnu osobnost prema odredbama kanonskoga prava te da nadležna crkvena vlast može osnivati, mijenjati, dokidati ili priznavati crkvene pravne osobe, prema odredbama kanonskoga prava. ${ }^{27}$ Kako je istaknuto u doktrini, “priznavajući javnu pravnu osobnost

27 O čl. 2. st. 2. - 3. Ugovora o pravnim pitanjima vidi Eterović, op. cit. u bilj. 1, str. 149 - 157. U navedenom kontekstu treba istaknuti da su spomenute odredbe Ugovora svojevremeno ignorirane evidentno protupravnim zahtjevima nadležnih državnih vlasti za mandata ministra financija Linića (2011. - 2014.) da se crkvene pravne osobe, a u prvom redu biskupije, imaju upisati u registar neprofitnih organizacija. Naime, prema čl. 2. st. 2. - 3. Ugovora pravne osobe Katoličke Crkve u hrvatskom pravnom sustavu imaju onu vrstu pravne osobnosti kakva je određena odredbama kanonskog prava te je pravo RH automatski priznaje. Ako, primjerice, pravna narav biskupija po kanonskom pravu - priznata i u hrvatskom pravnom sustavu - nije biti neprofitna organizacija, takav zahtjev državnih vlasti za upis biskupija u registar neprofitnih organizacija čini se neutemeljenim, kako po samoj kanonskoj naravi, tako i po nadzakonskim odredbama međunarodnog prava. U tom smislu kao načelo treba istaknuti da državna tijela nemaju pravo određivati narav pravnih osoba Katoličke Crkve, što se zahtjevom za upis u registar neprofitnih organizacija neposredno činilo. Pošalica koja je tih dana kružila među zainteresiranom javnošću, a koja je glasila "Zagrebačka biskupija, osnovana 1094. po sv. Ladislavu, pretvorena 2013. u neprofitnu organizaciju po ministru Liniću”, na sažet i precizan način izražava svu apsurdnost takvih zahtjeva; usp. https://www.24sata.hr/news/kraj-mutnog-poslovanja-linic-udara-i-po-crkvi-i-po-udrugama-328098 (20. srpnja 2020.). Nasreću, zakonodavac je, za razliku od pojedinih spomenutih struktura izvršne vlasti, ipak uzeo u obzir naše konkordatsko pravo, propisujući čl. 34. st. 5. - 6. Zakona o financijskom poslovanju i računovodstvu neprofitnih organizacija (Narodne novine, br. 121/2014) da ne postoji obveza vjerskih zajednica upisati se u Registar neprofitnih organizacija, tj. da za političke stranke i vjerske zajednice upis u Registar neprofitnih organizacija nije uvjet za dobivanje sredstava iz državnog proračuna, proračuna jedinica lokalne i područne (regionalne) samouprave i drugih javnih izvora. 
Katoličkoj crkvi i njezinim ustanovama, državna vlast priznaje da su te pravne osobe ustanovljene za opću korist, a njihova djelatnost spada u javnu službu". ${ }^{28}$ U pogledu I. knjige CIC-a, može se isto reći i za materiju crkvenih službi jer čl. 6. st. 1. navedenog ugovora određuje da je Katolička Crkva nadležna za sva crkvena imenovanja i dodjelu crkvenih službi, prema odredbama kanonskoga prava. Time se, naravno, implicite određuje i da Republika Hrvatska automatski priznaje sva crkvena imenovanja i dodjelu crkvenih službi bez ikakvih svojih daljnjih akata ili interferencije. ${ }^{29}$ Ostavljajući trenutačno ostala pitanja Općih odredbi CIC-a po strani te ujedno upućujući na relevantnu literaturu ${ }^{30}$, treba

28 Cit. Eterović, op. cit. u bilj. 1, str. 150. usp. i Zec, op. cit. u bilj. 20, str. 399 - 400.

29 O čl. 6. st. 1. Ugovora o pravnim pitanjima vidi Eterović, op. cit. u bilj. 1, str. 156 157, uz relevantne poredbene referencije; Jakulj, I., Pravni položaj Katoličke Crkve u Republici Hrvatskoj: od totalitarizma do demokracije, Crkva u svijetu, vol. 50, br. 3, 2015. str. 499. Čini nam se potrebnim još istaknuti da u navedenom kontekstu pravne osobnosti i crkvenih imenovanja sasvim posebno mjesto svakako zauzimaju jedina dva duhovna viteška reda koja priznaje i štiti Sveta Stolica: Suvereni Malteški viteški red i Viteški red Sv. Groba Jeruzalemskog. Oba viteška reda potječu još iz srednjeg vijeka. Prvi od njih, Suvereni Malteški viteški red, ima status suverenog subjekta međunarodnog prava te je kao takav uspostavio diplomatske odnose $s$ Republikom Hrvatskom još 22. prosinca 1992. Drugi od njih, Viteški red Sv. Groba Jeruzalemskog, stoji pod izravnom zaštitom Svete Stolice kao svojeg suverena pa stoga sam po sebi nije suvereni subjekt, no ima status pravne osobe u međunarodnom pravu. Budući da se spomenuti pojam "crkvenog imenovanja” iz čl. 6. st. 1. Ugovora o pravnim pitanjima odnosi i na imenovanja vitezova koji pripadaju tim dvama redovima, treba zaključiti da su takve viteške titule priznate eo ipso i $\mathrm{u}$ hrvatskom pravnom sustavu te se stoga mogu i koristiti u pravnom prometu; o navedena dva duhovna viteška reda vidi detaljnije Zovko D., Viteštvo danas. Što je zbilja, što je fantazija?, Zagreb, 2016., str. 71- 102, s uputama na brojnu daljnju literaturu. U navedenom kontekstu treba spomenuti i jednu odluku državnog Povjerenstva za odlučivanje o sukobu interesa (br. 711-I-530-P-235-17/18-02-11, od 13. travnja 2018., dostupnu na https:/www.sukobinteresa.hr/sites/default/files/ akti/2018/p-235-17-18-02.pdf). Premda se sa shvaćanjem Povjerenstva da članstvo u takvim duhovnim viteškim redovima "nije protivno načelima obnašanja javnih dužnosti u smislu čl. 5. Zakona o sprječavanju sukoba interesa, niti ... da bi sama činjenica članstva dovodila u pitanje nepristranost dužnosnika" treba bezrezervno složiti, nikako se ne može prihvatiti shvaćanje da je u navedenom kontekstu "titula viteza ... prvenstveno počasna i protokolarna titula”. Navedene viteške titule imaju svoj precizno uređen pravni status i značenje s pripadajućim obvezama i pravima $u$ (stoljećima postojećim) pravnim poredcima viteških duhovnih redova - priznatima na temelju Ugovora o pravnim pitanjima i u hrvatskom pravnom sustavu - koji se nipošto ne bi mogao svesti na puku "počast" i "protokol".

30 Jedina knjiga na hrvatskom jeziku koja u cjelini obrađuje materiju I. knjige CIC-a jest već navođena Brkan, J., Opće odredbe Zakonika kanonskog prava, Makarska, 1997. 
zaključno napomenuti da su se hrvatski državni sudovi u svojim recentnim odlukama izravno referirali na kanone I. knjige CIC-a, primjerice glede pravnih osoba, a posebice u kontekstu bratovština, njihove pravne naravi, osnutka, trajanja te pitanja pravnog sljedništva u slučaju njihova prestanka. ${ }^{31}$

II. knjiga CIC-a pod naslovom Božji narod (De populo Dei) (kann. 204 - 746) sadržava odredbe o vjernicima (obvezama i pravima svih vjernika, laicima, klericima, osobnim prelaturama te vjerničkim društvima), odredbe o hijerarhijskom uređenju Crkve, kako o vrhovnoj crkvenoj vlasti (Rimski prvosvećenik i biskupski zbor, biskupska sinoda, kardinali, Rimska kurija, izaslanici rimskog prvosvećenika), tako i o partikularnim crkvama i njihovim skupštinama (biskupi, uključujući i posebne odredbe o spriječenoj i praznoj stolici; skupštine partikularnih crkava s posebnim poglavljima o crkvenim pokrajinama i crkvenim regijama, metropolitima, krajevnim saborima i biskupskim konferencijama; unutrašnje uređenje partikularnih crkava s posebnim poglavljima o biskupijskim sinodama, biskupijskim kurijama, prezbiterijalnom vijeću i zboru savjetnika, kanoničkim kaptolima, pastoralnim vijećima, župama, župnicima i župnim vikarima, dekanima te rektorima crkava i kapelanima) te naposljetku odredbe o ustanovama posvećenog života (redovničke ustanove, svjetovne ustanove) te družbama apostolskog života. Odredbe II. knjige CIC-a izravni su normativni ključ za pravilno shvaćanje i tumačenje, primjerice, čl. 5. Ugovora o pravnim pitanjima koji određuje da isključivo na nadležnu crkvenu vlast spada slobodno uređivati vlastiti crkveni ustroj, osnivati, mijenjati i ukidati crkvene pokrajine, nadbiskupije, biskupije, apostolske administrature, teritorijalne prelature, teritorijalne opatije, osobne prelature, župe, ustanove posvećenoga života i družbe apostolskoga života te druge crkvene pravne osobe. ${ }^{32} \mathrm{U}$ pogledu II. knjige CIC-a

31 Vidi npr. Rješenje Županijskog suda u Splitu, Gžst-127/2015 od 15. prosinca 2017., u kojem se ističe da se "bratovština osniva u trenutku kad biskup potvrdi statut bratovštine (kan. 113. - 118. Zakonika kanonskog prava u svezi s člankom 2. Ugovora sa Sv. Stolicom)" te da "s obzirom da su bratovštine osnovane u kasnom srednjem i ranom novom vijeku bile crkvene institucije koje su se osnivale odobrenjem biskupa u trenutku potvrđivanja njihovog statuta od strane biskupa te da je biskup nadzirao njihov rad, nakon njihovog ukidanja pravni sljednici postale su osobe određene statutom bratovštine ili neposredno viša crkvena pravna osoba (kan. 123. Zakonika kanonskog prava u svezi s člankom 2. Ugovora sa Sv. Stolicom), a to su najčešće bile župne crkve". O navedenim kanonima CIC-a vidi detaljnije Brkan, Opće odredbe, op. cit. u bilj. 16, str. $196-210$ i $217-218$.

32 O čl. 5. Ugovora o pravnim pitanjima, vidi Eterović, op. cit. u bilj. 1, str. 156 - 157, uz relevantne referencije na kan. 373. CIC-a, koji određuje da samo vrhovna crkvena vlast može osnivati partikularne Crkve te poredbeno konkordatsko pravo; usporedi Jakulj, op. cit. u bilj. 29, str. 499. 
već rečeno vrijedi i za čl. 6. st. 2., koji normira da su imenovanje, premještaj i smjena biskupa u isključivoj nadležnosti Svete Stolice, što nije bio slučaj u određenim prethodnim državama koje su postojale na hrvatskom tlu ${ }^{33}$, te čl. 14. st. l. istog Ugovora, koji određuje da Republika Hrvatska priznaje pravo vjernika da osnivaju društva s ciljevima koji su vlastiti Crkvi. ${ }^{34}$ Upućujući na relevantne domaće monografije o materiji II. knjige Zakonika ${ }^{35}$, potrebno je istaknuti da su se hrvatski državni sudovi u novije vrijeme u više navrata pozivali na kanone II. knjige CIC-a. Primjerice, zaključujući u povodu tužbe jednog svećenika protiv njegove biskupije na isplatu plaće da svećenik nije u radnom odnosu s biskupijom, niti da postoji njezina obveza na isplatu plaće te da, shodno tome, nije riječ o radnopravnom predmetu, već o pitanju crkvenog imenovanja u smislu čl. 6. st. 1 . Ugovora o pravnim pitanjima, hrvatski su se sudovi pozvali explicite na kan. 281. § 1. te kan. 282. § 2. CIC-a koji uređuju pitanja naknada klericima za njihovu crkvenu službu te dobara koja steknu prigodom vršenja crkvene službe. ${ }^{36}$ Daljnji

33 Na ovom se mjestu vrijedi podsjetiti na činjenicu da je još u Kraljevini Jugoslaviji, sukladno pravilima u Hrvatskoj tada još uvijek važećeg Austrijskog konkordata iz 1855., kralj morao dati pristanak na imenovanje biskupa. Prema Ugovoru o pravnim pitanjima imenovanje, premještaj i smjena biskupa u isključivoj su nadležnosti Svete Stolice, uz obvezu Svete Stolice da prije objavljivanja imenovanja dijecezanskih biskupa o tome, na povjerljiv način, obavijesti Vladu Republike Hrvatske (čl. 6. st. 2.). Ta obveza ne vrijedi za pomoćne biskupe. O čl. 6. st. 2. Ugovora o pravnim pitanjima vidi Eterović, op. cit. u bilj. 1, str. 158 - 162, uz relevantne poredbene referencije; Jakulj, op. cit. u bilj. 29, str. 499.

O vjerničkim društvima u navedenom kontekstu uz relevantne poredbene referencije vidi Eterović, op. cit. u bilj. 1, str. 194 - 197; Zec, op. cit. u bilj. 20, str. 403 - 404.

35 Cjelovitu obradu II. knjige CIC-a pružio je zasad jedino Pranjić, P., Božji narod - II. knjiga ZKP-a, Sarajevo, 2012.; temeljne i vrijedne priloge o II. knjizi CIC-a predstavljaju i sljedeće monografije i zbornici: Baćak, A. A. (ur.), Novo pravo ustanova posvećenoga života, Zbornik radova Desetog redovničkog tjedna, Zagreb, 1991.; Brkan, J., Župa u zakonodavstvu Katoličke crkve, Split, 2004.; Brkan, J., Obveze i prava vjernika laika, Split, 2005.; Brkan, J., Ustanove posvećenoga života $i$ družbe apostolskoga života prema Zakoniku kanonskoga prava, Šibenik, 2007.; Šalković J., Obveze i prava vjernika laika (kann. 224-231). Poslanje i djelovanje, Zagreb, 2009.; Šalković, J. (ur.), Vjernici, društva, pokreti, Zbornik radova IV. međunarodnog znanstvenog simpozija crkvenih pravnika u Zagrebu, 29. - 30. listopada 2010., Zagreb, 2011.; Blažević, V., Crkveni partikularni sabori i dijecezanske sinode na području Hrvatske i drugih južnoslavenskih zemalja, Zagreb, 2012.; Brkan, J., Klerici u zakonodavstvu Katoličke Crkve, Split, 2012.; Blažević, V., Župe i župnici. Pravno-pastoralni repetitorij, Zagreb, 2014.; Šalković, J. (ur.), Zakon u životu partikularne Crkve, Zbornik radova VIII. međunarodnog znanstvenog simpozija crkvenih pravnika u Trogiru - Čiovo, 9. - 10. listopada 2014., Zagreb, 2016.

36 Vidi Presudu i rješenje Vrhovnog suda RH, Revr-205/03-2 od 23. travnja 2003. u kojoj se ističe: "Po ocjeni ovog revizijskog suda niži sudovi pravilno su zaključili 
slučajevi u kojima su se državni sudovi pozivali na II. knjigu CIC-a odnosili su se na pravno uređenje župe kao zajednice vjernika. Tako se u jednom slučaju pred Županijskim sudom u Splitu pojavilo pitanje može li župa biti stranka u građanskom postupku. Uporabivši u nama relevantnom dijelu obrazloženja tog predmeta kratku i preciznu formulaciju - “...po zakoniku Kanonskog prava kojeg valja primijeniti sukladno međunarodnom ugovoru..." - koju bi se bez ikakve dvojbe kao uzornu moglo navesti u svim usporedivim slučajevima primjene kanonskog prava, navedeni sud zaključio je da župa može biti stranka u građanskom postupku, pozvavši se na CIC, kan. 515. koji, inter alia, određuje da zakonito osnovana župa ipso iure ima pravnu osobnost. ${ }^{37} \mathrm{U}$ drugom predmetu,

da tužitelj kao svećenik nije u radnom odnosu sa tuženicom niti postoji obveza tuženice na isplatu plaće, odnosno naknade plaće tužitelju, pri čemu su niži sudovi ukazali na odredbu Kan. 281. paragraf 1. Zakonika kanonskog prava, jer pravilnim tumačenjem te odredbe imajući na umu i Taksovnik tužene biskupije proizlazi, da svećenici na službi u toj biskupiji - kao uostalom i u drugim biskupijama u Republici Hrvatskoj - imaju pravo sami naplaćivati od vjernika naknadu za mise, vjenčanja, sprovode, kao i naknade za pastoralnu pomoć (nagrada za propovijedi, za ispovijedi) ... Isto tako, i prema Kan. 282. paragraf 2. Kanonskog prava dobra koja klerici (svećenici) steknu prigodom vršenja crkvene službe, a koja preostanu pošto osiguraju dolično uzdržavanje i obavljanje svih dužnosti svojeg staleža trebali bi upotrebljavati za dobrobit crkve i za djela dobrotvornosti. Sve te odredbe kanonskog prava i po shvaćanju ovog Vrhovnog suda ukazuju, da ne postoji obveza crkve na isplatu plaće, odnosno naknade plaće svojim svećenicima koji svoje prihode ostvaruje iz prihoda prikupljenih od vjernika čija je visina određena spomenutom Taksovnikom, pri čemu ako takvi prihodi prelaze zadovoljenje potreba svećenika i nadilaze pravičnu naknadu dužni su ih svećenici upotrijebiti za druge potrebe crkve kao i u dobrotvorne svrhe."; usporedi i Odluku Ustavnog suda RH, U-III-2997/2003 od 4. ožujka 2004., u čijem se obrazloženju glede istog pravnog odnosa ističe da "analizom utvrđenja iz postupaka koji su prethodili ustavnosudskom postupku, kao i činjenice da je u utuženom razdoblju podnositelj prihode za svoj rad ostvarivao temeljem odredbe Kanona 281. paragrafa 1. Zakonika kanonskog prava (naknade prilikom vršenja crkvenih obreda, milodari i sl.), te da s tuženom nije zaključio ugovor o radu slijedom kojeg bi ostvarivao pravo na isplatu plaće, Sud osporenu presudu Vrhovnog suda Republike Hrvatske smatra donesenom pravilnom primjenom mjerodavnog materijalnog prava i istom ne utvrđuje u materijalnopravnom smislu povrijeđenim ustavno pravo propisano odredbom članka 14. stavka 2. Ustava Republike Hrvatske."; o navedenim kanonima CIC-a vidi npr. Brkan, J., Klerici..., op. cit. u bilj. 35, a posebice poglavlje III., t. 9 i 10.

37 Vidi Rješenje Županijskog suda u Splitu, Gžp-1093/2014, od 14. rujna 2015. u čijem se obrazloženju navodi: "Po zakoniku Kanonskog prava kojeg valja primijeniti sukladno međunarodnom ugovoru sklopljenom između Republike Hrvatske i Vatikana (tj. Svete Stolice, op. a.,) i to paragrafu 515. župa je određena zajednica vjernika trajno ustanovljena u partikularnoj crkvi, za koju je pastirska briga pod vlašću 
pak, također pred istim Županijskim sudom, pojavilo se pitanje tko zastupa župu kao pravnu osobu. U toj se prigodi sud pozvao na CIC, kan. 532., koji određuje da župnik zastupa župu u svim pravnim poslovima. ${ }^{38}$

III. knjiga CIC-a pod naslovom Naučiteljska služba Crkve (De Ecclesiae munere docendi) (kann. 747 - 833) sadržava odredbe o naviještanju Božje riječi (propovijedanje Božje riječi, katehetsko poučavanje), crkvenoj misijskoj djelatnosti, katoličkom odgoju (škole, katolička sveučilišta i druge visokoškolske ustanove, crkvena sveučilišta i fakulteti), sredstvima društvenog priopćavanja i posebno knjigama te naposljetku ispovijesti vjere. III. knjiga CIC-a relevantan je konceptualni i normativni okvir za shvaćanje nekolicine odredaba Ugovora o pravnim pitanjima. U tom smislu treba navesti čl. 12. Ugovora, kojim je određeno da je Katoličkoj Crkvi zajamčena sloboda tiska, tiskanje i širenje knjiga, novina, časopisa te druge djelatnosti povezane s njezinim poslanjem, kao i da Katolička Crkva ima pristup i na državna sredstva javnoga priopćivanja (novine, radio, televizija) te da ima pravo osnivati i obavljati djelatnosti radija i televizije. Jednako tako, u navedenom kontekstu treba istaknuti i čl. 15. Ugovora koji određuje da Katolička Crkva ima pravo osnivati obrazovne ustanove bilo kojega stupnja i njima upravljati prema vlastitim pravilima (tj. odredbama kanonskoga prava), poštujući odredbe zakonodavstva Republike Hrvatske. Materija iz navedenih odredaba Ugovora o pravnim pitanjima (sredstva društvenog priopćavanja, katolički odgoj) detaljnije je razrađena u Ugovoru o suradnji na području odgoja i kulture..$^{39}$ III. knjiga CIC-a nedvojbeno je ključ za pravilno razumijevanje i

dijecezanskog biskupa povjerena župniku kao njezinu vlastitom pastiru. Osnivati, ukidati i obnavljati župe zadaća je samog dijecezanskog biskupa koji neka župe ne osniva, ne ukida i znatnije ne obnavlja, osim pošto se posavjetuje s prezbiterskim vijećem. Župa zakonito osnovana po samom pravu ima pravnu osobnost.".

38 Vidi Rješenje Županijskog suda u Splitu, Gž-3507/15-2, od 28. siječnja 2016. u kojem se, među ostalim, ističe: "Prema odredbama kanonskoga prava K. crkva sv. P. u K. N. nije jedna od crkvenih pravnih osoba Katoličke Crkve u Republici Hrvatskoj, nego to može biti sukladno kanonu 515. § 3. Zakonika kanonskog prava samo Ž. sv. P. ap. u K. N., koju prema kanonu 532. Zakonika kanonskoga prava zastupa u pravnim poslovima župnik. U prilog toga govori činjenica da je u konkretnom slučaju odgovor na tužbu dao župnik Župe sv. P. ap. u K. N., koji je i opunomoćio odvjetnika D. V. iz K. K. za zastupanje u ovoj parnici.”; o navedenim i drugim kanonima CIC-a koji uređuju župu kao oblik crkvenog ustroja vidi. npr. Brkan, Župa u zakonodavstvu..., op. cit. u bilj. 35, str. 58 - 269, s uputama na daljnju literaturu.

Općenito o pristupu Katoličke Crkve sredstvima javnog priopćavanja u Republici Hrvatskoj na temelju odredaba konkordatskog prava vidi Mikulić, E.; Šalković, J., Pravo i načela pristupa "medijskom prostoru” prema ugovorima izmedu Svete Stolice i Republike Hrvatske, u: Valković, J. (ur.), Vjerska tematika u hrvatskom medijskom prostoru, Zbornik radova znanstvenog simpozija i projekta na Hrvatskom katoličkom sveučilištu u 
odredaba tog međunarodnog ugovora, pa je stoga sretna okolnost da je u nas u novije vrijeme objavljen iscrpan komentar navedene knjige CIC-a. ${ }^{40}$ Hrvatska sudska praksa također je imala prigodu referirati se u svojim odlukama na materiju III. knjige Zakonika. Naime, na temelju čl. 3. st. 2. Ugovora o suradnji na području odgoja i kulture, koji određuje da vjeroučitelji moraju imati ispravu o kanonskome mandatu (missio canonica) koju je izdao dijecezanski biskup te da opoziv mandata nosi sa sobom neposredni gubitak prava na predavanje katoličkoga vjeronauka, taj specifični kanonski institut uveden je i u hrvatski pravni sustav. Jedan spor o missio canonica, tzv. slučaj Travaš, postao je svojevrsni cause célèbre hrvatskog pravosuđa, prošavši kroz sve njegove instancije sve do Europskog suda za ljudska prava u Strasbourgu. Budući da je o navedenoj problematici već pisano u našoj kanonskopravnoj i civilnopravnoj literaturi, upućujemo ovom prilikom na njezinu detaljniju obradu u već objavljenim radovima. ${ }^{41}$

Zagrebu, Zagreb, 2019., str. 13 - 28; usporedi i Eterović, op. cit. u bilj. 1, str. 253 256; Zec, op. cit. u bilj. 20, str. 401 - 402; o pravnom uređenju katoličkog vjeronauka u školskom sustavu Republike Hrvatske, polazeći od konkordatskog prava, uz relevantne poredbene referencije vidi Eterović, op. cit. u bilj. 1, str. 205 - 223; Šalković, J., Pravni okvir katoličkog vjeronauka u javnim školama: aktualnosti i perspektive, u: Razum, R. (ur.), Vjeronauk nakon dvadeset godina: izazov Crkvi i školi, Zbornik radova sa znanstvenog simpozija "Vjeronauk nakon dvadeset godina: izazov Crkvi i školi”, Zagreb, 2011., str. 121 - 141. Inače, Vlada Republike Hrvatske i HBK sklopili su Ugovor o katoličkom vjeronauku u javnim školama i vjerskom odgoju u javnim predškolskim ustanovama 1999. godine. U navedenom kontekstu treba nadalje istaknuti da je Ugovor između Vlade Republike Hrvatske i HBK-a o katoličkim osnovnim i srednjim školama sklopljen 2011. godine. Danas u Republici Hrvatskoj djeluju 24 katoličke škole, tj. 12 osnovnih škola te 12 srednjih škola koje su gotovo u pravilu klasične gimnazije; općenito o katoličkim školama u poredbenom kontekstu vidi Eterović, op. cit. u bilj. 1, str. 233 - 24l; općenito o crkvenom visokom školstvu na temelju odredaba našeg konkordatskog prava vidi Šanjek, F., Kakve nam mogućnosti crkvenog visokog školstva nude Ugovori RH i Svete Stolice, Riječki teološki časopis, vol. 5, br. 2, 1997., str. 295 - 301; usporedi i Berljak, M., Položaj i djelovanje Katoličkoga bogoslovnog fakulteta u sastavu Sveučilišta u Zagrebu. Dvadeseta obljetnica potpisivanja Ugovora, Bogoslovska smotra, vol. 86, br. 1, 2016., str. 31 - 65. U tom smislu treba posebice napomenuti da je 3. lipnja 2006. godine osnovano i Hrvatsko katoličko sveučilište Dekretom o osnivanju Hrvatskog katoličkog sveučilišta sa sjedištem u Zagrebu br. 1273/2006. kardinala Josipa Bozanića, zagrebačkog nadbiskupa i metropolita, koje se u međuvremenu razvija u respektabilnu akademsku instituciju; o navedenoj problematici vidi i Šalković, J., Katolička sveučilišta (kann. 807-814), Bogoslovska smotra, vol. 77, br. 4, 2008., str. 807 - 838.

40 Šalković, J., Pravni elementi evangelizacijskog poslanja Crkve. Komentar III. knjige Zakonika, Zagreb, 2013.

${ }^{41}$ O navedenoj problematici, uključujući kanonskopravna, konkordatskopravna i ustavnopravna pitanja vidi Šalković, Pravni okvir katoličkog vjeronauka..., op. cit. u bilj. 
IV. knjiga CIC-a pod naslovom Posvetiteljska služba Crkve (De Ecclesiae munere sanctificandi) (kann. 834 - 1253) sadržava prije svega iscrpne odredbe o sedam sakramenata (krst, potvrda, presveta euharistija, pokora, bolesničko pomazanje, sveti red i ženidba), a zatim i odredbe o ostalim bogoslovnim činima (blagoslovine, časoslov, crkveni sprovod, štovanje svetaca, svetih likova i svetih moći, zavjet i prisega) te naposljetku o svetim mjestima (crkve, kapele, svetišta, oltari, groblja) i svetim vremenima (blagdani, dani pokore). Odredbe Ugovora o pravnim pitanjima o slobodi obavljanja bogoslužja (čl. 7.) ${ }^{42}$, neradnim danima (nedjeljama i svetkovinama) (čl. 9. ${ }^{43}$, izgradnji bogoštovnih prostora i crkvenih zgrada (čl. 11.) ${ }^{44}$ te kanonskoj ženidbi (čl. 13.) ${ }^{45}$ ne mogu se cjelovito shvatiti u

39, str. 130 - 140; usporedi i Eterović, op. cit. u bilj. 1, str. 220 - 222, s poredbenim referencijama; Milotić, I., Radni odnos i kanonski mandat u RH - u povodu jedne presude europskog suda za ljudska prava u Strasbourgu, Pravo i porezi, br. 11, 2016., str. 17 - 23.

O čl. 7. Ugovora o pravnim pitanjima vidi Eterović, op. cit. u bilj. 1, str. 163 - 165, uz relevantne poredbene referencije. U tom kontekstu valja se prisjetiti i određenih događaja iz razdoblja drugog mandata predsjednika Stjepana Mesića (2005. - 2010.), kada je Mesić u više navrata, pozivajući se na svoje ovlasti vrhovnog zapovjednika Oružanih snaga Republike Hrvatske, putem medija - uglavnom iz idejnih i svjetonazorskih razloga - zaprijetio tadašnjem vojnom ordinariju mons. Jurju Jezerincu da će mu zabraniti ulazak u vojarne; usporedi www.poslovni.hr/hrvatska/mesic-jezerincu-mogu-zabraniti-ulazak-u-vojarne-60287 (20. srpnja 2020.). Navedena bi se zabrana, u slučaju liturgijskih slavlja, protivila ne samo spomenutoj konkordatskoj odredbi o nepovredivosti mjesta za bogoštovlje, koja se svakako odnosi i na takva mjesta u vojarnama, već posebice i čl. 10. Pravilnika o ustrojstvu i djelovanju vojnog ordinarijata u Republici Hrvatskoj, koji određuje da su sakralni objekti u vojarnama pod jurisdikcijom vojnog ordinarija (a ne državnih vlasti).

43 O čl. 9. Ugovora o pravnim pitanjima vidi Eterović, op. cit. u bilj. 1, str. 169 - 170. Navedeni članak Ugovora kao nadzakonski akt izrijekom propisuje da je nedjelja neradni dan. U ovom kontekstu potrebno je kritički istaknuti da je Ustavni sud odlukom U-I-642/2009 od 19. lipnja 2009. godine, ukidajući zbog neustavnosti pojedine odredbe Zakona o trgovini iz 2008. godine, kojima je, inter alia, uz brojne iznimke, nedjelja proglašena neradnim danom, “...de facto suspendirao članak 9. Ugovora o pravnim pitanjima (u dijelu u kojem se navodi da je nedjelja neradni dan), mimo izričite ustavne odredbe (čl. 134.) da se odredbe međunarodnog ugovora mogu mijenjati ili ukidati samo na način koji je njime predviđen ili suglasno općim pravilima međunarodnog prava."; cit. Staničić, F., Zabrana rada nedjeljom u trgovini-ustavnopravni aspekti, Informator, br. 6625, 2020., str. 15.

$44 \mathrm{O}$ čl. 11. Ugovora o pravnim pitanjima vidi Eterović, op. cit. u bilj. 1, str. 173 - 176, s relevantnim referencijama na odgovarajuće kanone CIC-a i poredbeno konkordatsko pravo.

45 Općenito o kanonskoj ženidbi kao instituciji te odredbama koje je uređuju u poredbenom konkordatskom kontekstu vidi Eterović, op. cit. u bilj. 1, str. 178 - 186; Ška- 
svom tekstu i kontekstu bez poznavanja IV. knjige CIC-a, o kojoj na hrvatskom jeziku postoji doista opsežna pravna književnost. ${ }^{46}$ Hrvatski državni sudovi također su se u nekolicini slučajeva pozivali na kanone IV. knjige CIC-a. Tako se, primjerice, u već spomenutom slučaju (u kontekstu II. knjige CIC-a) tužbe jednog svećenika protiv njegove biskupije na isplatu plaće Vrhovni sud RH, zaključujući da pravni odnos svećenika i njegove biskupije nije radni odnos, pozvao glede pitanja naknada klericima za njihovu crkvenu službu, osim ostalih spomenutih kanona CIC-a (kan. 281. § 1. te kan. 282. § 2.) i na kan. 952. $\S$ 1. koji uređuje visinu priloga za slavljenje i namjenu mise. ${ }^{47}$ Nadalje, Vrhovni sud RH u jednom je slučaju, razmatrajući u kontekstu čl. 284. Zakona o kaznenom postupku ${ }^{48}$ razliku između pojedinih kategorija osoba nesposobnih za svjedočenje (1. osoba koja bi svojim iskazom povrijedila zakonom ustanovljenu obvezu čuvanja tajnosti podataka, dok je nadležno tijelo ne oslobodi te obveze; 2. branitelj okrivljenika, osim ako to sam okrivljenik ne zahtijeva; 3. okrivljenik u postupku u kojem su primijenjene odredbe o spajanju/razdvajanju postupka; 4. vjerski ispovjednik o sadržaju ispovijedi), zaključio da su sve navedene osobe tek relativno nesposobne za svjedočenje, tj. da one ne smiju biti ispitane kao svjedoci sve dok su povezane s potrebom očuvanja nekog drugog društvenog interesa koji je jači od interesa vođenja kaznenog postupka, osim vjerskog ispovjednika koji je apsolutno nesposoban za svjedočenje. Posebno je interesantno

labrin, N., Kanonska ženidba s građanskim učincima, Vjesnik Đakovačke i Srijemske biskupije, vol. 125, br. 3, 1997., str. 187 - 196; Zec, op. cit. u bilj. 20, str. $402-403$.

46 Cjelovitu obradu IV. knjige CIC-a pružio je Pranjić, P., Posvetiteljska služba Crkve. Komentar 4. knjige ZKP-a, Zagreb, 2016.; pojedini temeljni instituti IV. knjige obrađeni su u sljedećim monografijama: Škalabrin, N., Ženidba. Pravno-pastoralni priručnik, Đakovo, 1995.; Berljak, M., Kanonski oblik ženidbe. Povijesni razvoj - Zakonik kanonskoga prava/1983., Zagreb, 1999.; Berljak, M., Sakramenti ozdravljenja. Pokora i bolesničko pomazanje: pravno-pastoralni komentar, Zagreb, 2004.; Blažević, V., Ženidbeno pravo Katoličke crkve. Pravno-pastoralni priručnik, Zagreb, 2004.; Berljak, M., Kumovi svjedoci. Krst - Potvrda - Ženidba, Zagreb, 2010.; Šalković, J. (ur.), Zaručništvo i priprava za ženidbu, Zbornik radova VII. međunarodnog znanstvenog simpozija crkvenih pravnika u Subotici, 11. - 12. listopada 2013., Zagreb, 2015.

47 Vidi Presudu i rješenje Vrhovnog suda RH, Revr-205/03-2, od 23. travnja 2003. u kojoj se ističe da "prema Kan. 952 paragraf 1. Kanonskog prava crkvena tijela (pokrajinski sabor ili pokrajinska biskupska skupština) svojom odlukom utvrđuju za svu pokrajinu koliki prilog treba dati za slavljenje i namjenu mise, te svećeniku nije dopušteno tražiti veći iznos ali mu je dopušteno ipak primiti dobrovoljno ponuđeni, dapače i manji prilog od onog određenog za namjenu mise."; o navedenoj odredbi CIC-a vidi Pranjić, op. cit. u bilj. 46, str. 108.

48 Narodne novine, br. 152/2008, 76/2009,80/2011, 121/2011, 91/2012, 143/2012, 56 /2013, 145/2013, 152/2014, 70/2017, 126/2019. 
napomenuti da se Vrhovni sud RH u obrazloženju tog svojeg shvaćanja o razlici između apsolutne i relativne nesposobnosti za svjedočenje nije pozvao na čl. 8. st. 2. Ugovora o pravnim pitanjima, koji određuje da je ispovjedna tajna u svakom slučaju nepovrediva ${ }^{49}$, već izravno na CIC, kan. 983. § 1., parafrazirajući navedeni kanon uz vlastiti komentar: "Iznimke postoje za svaku od tih osoba, osim za vjerskog ispovjednika (točka 4. članka 284. ZKP/08.) koji bi trebao svjedočiti o sadržaju ispovijedi jer se radi o ispovjednoj tajni, tzv. sakramentalnom pečatu koji je nepovrediv i apsolutan. Ovo zato što nije moguće da itko ikada oslobodi ispovjednika čuvanja sakramentalnog pečata jer ispovjedna tajna nije vezana uz osobu nego uz sakrament (Kan. 983. § 1. Zakonika o kanonskom pravu). Zato je vjerski ispovjednik apsolutno nesposoban za svjedočenje u kaznenom postupku." ${ }^{50}$. Mora se primijetiti da je Vrhovni sud RH u citiranom obrazloženju svoje odluke na optimalan način povezao znanja iz teologije, kanonskog prava i kaznenog procesnog prava. Naposljetku, posebno je zanimljiv jedan slučaj, vođen pred Općinskim građanskim sudom u Zagrebu, u kojem je tužitelj zahtijevao, sukladno čl. 22. st. 1. tada važećeg Zakona o javnom priopćavanju (Narodne novine, br. 83/1996), naknadu štete prouzročenu od strane nakladnika objavom informacije u javnom glasilu. Jedno od pitanja koje se postavilo u ovom pomalo apartnom slučaju u kontekstu spomenute naknade štete jest i je li tužitelj kao navodni "priznati stručnjak za područje ezoterije i uopće duhovnog iscjeljenja" obavljao egzorcizme u smislu kako ih definira katolička doktrina i je li za to, budući da nije svećenik, mogao imati dozvolu Katoličke Crkve. Stoga se navedeni sud u obrazloženju svoje odluke trebao pozvati i na CIC, kan. 1172. - koji određuje da nitko ne može zakonito obavljati egzorcizme nad opsjednutima, osim ako je od mjesnog ordinarija dobio posebnu i izričitu dozvolu, koju može dobiti samo svećenik koji se odlikuje pobožnošću, znanjem, razboritošću i neporočnošću života - kako bi se utvrdilo da je odgovor na oba spomenuta pitanja negativan, što je, inter alia, dovelo i do odluke o odbijanju tužbenog zahtjeva. ${ }^{51}$

49 O čl. 8. st. 2 Ugovora o pravnim pitanjima, koji određuje nepovredivost ispovjedne tajne, vidi Eterović, op. cit. u bilj. 1, str. 167 - 168, uz relevantne poredbene referencije; usporedi i Pleić, M.; Vukušić, I., Neka pitanja suradnje države i Katoličke Crkve u području kaznenog prava, Zbornik radova Pravnog fakulteta u Splitu, vol. 57, br. 3, 2020., str. 770 - 772 i $777-780$.

50 Rješenje Vrhovnog suda RH, I Kž-Us 92/15.-4, od 25. kolovoza 2015.; o navedenoj odredbi CIC-a vidi Pranjić, op. cit. u bilj. 46, str. 134; o značenju te odredbe u kaznenopravnom kontekstu vidi Pleić; Vukušić, op. cit. u bilj. 49, loc. cit.

51 Vidi Presudu i rješenje Općinskog građanskog suda u Zagrebu, Pn-1874/13-68, od 7. srpnja 2014. u kojoj se, među ostalim, navodi i sljedeće: "Na upit o usporedbi postupka koji je provodio tužitelj s onim koji propisuje Katolička Crkva, svjedok je rekao da bi se postupak tužitelja prije mogao opisati kao jedan ezoterijsko-okultistički 
Premda se u navedenom slučaju kanonsko pravo zapravo nije primijenilo na temelju međunarodnih ugovora između Svete Stolice i Republike Hrvatske, navedeni predmet rječito svjedoči o tome da relevantnost kanonskog prava u hrvatskoj sudskoj praksi može imati i još šire okvire.

V. knjiga CIC-a pod naslovom Vremenita crkvena dobra (De bonis Ecclesiae temporalibus) (kann. 1254 - 1310) sadržava odredbe o stjecanju dobara, upravljanju dobrima, ugovorima i napose o otuđenju te naposljetku o nabožnim odredbama općenito i nabožnim zakladama. Posebice čl. 10. st. 1. Ugovora o pravnim pitanjima - koji određuje da crkvene pravne osobe mogu kupovati, posjedovati, koristiti ili otuđivati pokretna i nepokretna dobra te stjecati i otuđivati imovinska prava, prema odredbama kanonskoga prava i zakonodavstva Republike Hrvatske - oslanja se na odredbe V. knjige CIC-a. Premda bi se na prvi pogled, imajući u vidu samo građanskopravnu doktrinu, moglo učiniti da se navedena odredba odnosi isključivo na stjecanja i otuđivanja na temelju pravnog posla, treba voditi računa o činjenici da sistematika CIC-a uvrštava, primjerice, i praescriptio (dosjelost, zastara) u materiju stjecanja dobara. O problematici preskripcije, kao i određenim drugim pitanjima vezanim uz primjenu čl. 10. st. l. Ugovora o pravnim pitanjima, prije svega o pitanju kako postupiti u slučajevima nesuglasnosti između "kanonskoga prava i zakonodavstva Republike Hrvatske" koje ta odredba Ugovora ravnopravno navodi kao pravne izvore, bit će detaljnije riječi u sljedećem poglavlju ovoga rada. Na ovom mjestu potrebno je, kao i glede ostalih knjiga CIC-a, uputiti na relevantnu domaću literaturu o V. knjizi CIC-a ${ }^{52}$ te prikazati judikaturu hrvatskih državnih sudova u kojoj kanoni o vremenitim

obred koji nema nikakve veze s egzorcizmom Katoličke Crkve koji mogu obavljati samo katolički svećenici koji za to imaju posebne dozvole odnosno dozvolu svog biskupa u skladu s Paragrafom 1172 Crkvenog zakona (tj. Zakonika Kanonskog prava, op. a.). Obred tužitelja sastojao se od polaganja ruku na pacijente i pokreta ruku koji bi upućivali na odstranjivanje negativnih energija ili bića... Nadalje je utvrđeno i da je u spornom članku citiran dio pisma don G. A. čiju vjerodostojnost tužitelj nije osporio te je i sam priznao da ga je dao autoru članka, a okolnost da u članku nije objavljeno i drugo pismo upućeno od strane iste osobe tužitelju kojim bi autor pisma tužitelju odobrio ono što radi ne znači da bi time nastala za tužitelja šteta s obzirom da se radilo o djelatnosti egzorcizma za koju mu odobrenje nije mogao dati svećenik koji je uputio pismo već kako to proizlazi iz Zakonika kanonskog prava i to paragrafa 1172, prema Katoličkoj Crkvi time se može baviti samo onaj tko je od mjesnog ordinarija dobio posebnu i izričitu dozvolu, te se time može baviti samo svećenik, a isto proizlazi i iz potvrde Nadbiskupije Zagrebačke Zagreb, Nadbiskupskog duhovnog stola od 19. veljače 2001. g.”. O kan. 1172. CIC-a vidi Pranjić, op. cit. u bilj. 46, str. $306-307$.

52 Postoje čak tri cjelovite i kvalitetne obrade V. knjige CIC-a o vremenitim crkvenim dobrima na hrvatskom jeziku: Brkan, J., Crkvena vremenita dobra. Temeljni kanoni 
crkvenim dobrima predstavljaju relevantan normativni sadržaj. U navedenom kontekstu ističe se jedna odluka Županijskog suda u Zadru iz 2019. godine. U određenom vlasničkopravnom predmetu, koji ima svoje pravno ishodište još u agrarnoj reformi u Kraljevini SHS/Jugoslaviji, a čiji se sukus, prema "narodskim" riječima tužitelja, sastoji u tome da je "kralj Petar platio u zlatnicima cjelokupno zemljište u Ž. dominikancima kako bi dominikanci to prepustili seljacima da obrađuju”, navedeni sud zauzeo je u obrazloženju odluke sljedeće shvaćanje: “To da bi Crkva vršila dodjelu zemljišta mještanima, a da o tome ne bi bio sastavljen kakav ugovor, malo je vjerojatno, jer kan. 1290.-1298. Zakonika kanonskog prava kao dio Zbirke kanonskih zakona, koja je proglašena "na svetkovinu Duhova 1917. godine" sa izmjenama objavljen 25. siječnja 1983. obvezuju Crkvu da svako stjecanje ili otuđenje imovine mora biti popraćeno pisanim dokumentima". ${ }^{53}$ Prema našem shvaćanju, za razliku od nekolicine prethodno spomenutih slučajeva pozivanja na kanonsko pravo kao pravni izvor, čini se da je Županijski sud u Zadru u navedenom dijelu obrazloženja napravio određene nedvojbene faktične i pravne pogreške. Kao prvo, važeći Zakonik kanonskog prava (Codex iuris canonici) “objavljen 25. siječnja 1983.” nije nikakva “izmjena” Zakonika kanonskog prava (Codex iuris canonici), proglašenog "na svetkovinu Duhova 1917. godine”, već nova kodifikacija! Kao drugo, ni stari CIC iz 1917., niti važeći CIC iz 1983. nisu dio nikakve "Zbirke kanonskih zakona", pri čemu se valjda "maglovito" mislilo na Corpus iuris canonici iz $1580 .{ }^{54}$ Kao treće, za predmet su navedeni kao relevantni kanoni 1290. - 1298. CIC-a iz 1983., koji reguliraju ugovore i napose otuđenje (de contractibus ac praesertim de alienatione). ${ }^{55}$ Međutim, "u doba kralja Petra" ti kanoni naravno nisu mogli biti na snazi, već odgovarajuće odredbe CIC-a iz 1917. (kann. 1529. - 1543.). Kao četvrto, i pravno najvažnije, jednostavno nije točan zaključak suda kako kanoni "obvezuju Crkvu da svako stjecanje ili otuđenje imovine mora biti popraćeno pisanim dokumentima". Ako se pri tome, s obzirom na kontekst predmeta, mislilo na pisani oblik ugovora kojim se otuđuju nekretnine kao pretpostavku njegove valjanosti, treba istaknuti da kako CIC iz 1983. (kan. 1290.), tako i CIC iz 1917. (kan. 1529.), sukladno već prethodno rečenom ${ }^{56}$, predviđaju kanonizaciju svjetovnog ugovornog prava

i upravljanje dobrima, Split, 2006.; Škalabrin, N., Vremenita crkvena dobra, Đakovo, 2008.; Pranjić, P., Vremenita dobra i vremenita dobra u Crkvi, Zagreb, 2013.

53 Rješenje Županijskog suda u Zadru, Gž-327/19-4, od 27. ožujka 2019.

54 Općenito o izvorima kanonskog prava usporedi Petrak, op. cit. u bilj. 25, str. 256 260, s uputama na daljnju relevantnu literaturu.

55 O navedenim kanonima CIC-a iz 1983. vidi Brkan, op. cit. u bilj. 17, str. 8 - 36; Škalabrin, op. cit. u bilj. 16, str. 173 - 199, s uputama na daljnju literaturu.

56 Vidi supra pod 1. 
određene države, pa stoga i odredaba o obliku određenog ugovora, uopće ne sadržavajući vlastite odredbe o tom pitanju! Sve u svemu, nažalost, treba zaključiti da obrazloženje sudske odluke u ovom predmetu ne otkriva detaljnije poznavanje ni izvora kanonskog prava, ni njihova sadržaja.

VI. knjiga CIC-a pod naslovom Kaznene mjere u Crkvi (De sanctionibus in Ecclesia) (kann. 1311 - 1399) sadržava u prvom dijelu opće odredbe o kažnjivim djelima i kaznama (kažnjavanje kažnjivih djela općenito; kazneni zakon i kaznena zapovijed; podložnik kaznenih mjera; kazne i ostala kažnjavanja uz zasebna poglavlja o cenzurama, okajničkim kaznama te kaznenim lijekovima i pokorama; primjenjivanje kazni; prestanak kazni), dok drugi dio navedene knjige uređuje kazne za pojedinačna kažnjiva djela (kažnjiva djela protiv vjere i jedinstva crkve; protupravno prisvajanje crkvenih služba i kažnjiva djela u njihovu vršenju; zlodjelo potvore i krivotvorenja; kažnjiva djela protiv posebnih obveza; kažnjiva djela protiv ljudskog života i slobode). Odredbe VI. knjige također su temelj za pravilno shvaćanje pojedinih odredaba međunarodnih ugovora između Svete Stolice i Republike Hrvatske. Primjerice, čl. 6. st. 3. Ugovora između Svete Stolice i Republike Hrvatske o dušobrižništvu katoličkih vjernika, pripadnika oružanih snaga i redarstvenih službi Republike Hrvatske, koji određuje da ako bi član klera Vojnoga ordinarijata morao biti podvrgnut stegovnim mjerama vojne naravi, nadležni zapovjednik poduzet će predviđene korake, uz prethodni dogovor s vojnim ordinarijem, dok će vojni ordinarij obavijestiti vojnu vlast o mogućim kanonskim kaznenim mjerama koje je poduzeo u određenim slučajevima. ${ }^{57}$ Po sebi je razumljivo da adekvatno shvaćanje o tome što su kanonske kaznene mjere - navedene u spomenutoj odredbi Ugovora kao relevantan normativni koncept - pretpostavlja određeno poznavanje VI. knjige CIC-a te pravne literature o navedenoj problematici, koja postoji i na hrvatskom jeziku. ${ }^{58}$ Prema našim spoznajama, hrvatski državni sudovi nisu se u svojoj praksi do sada pozivali na kanone VI. knjige CIC-a, što ne znači da do toga neće doći pro futuro.

VII. i posljednja knjiga CIC-a pod naslovom Postupci (De processibus) (kann. 1400 - 1752) sastoji se od pet dijelova. Prvi dio uređuje sudstvo općenito (mjerodavno sudište; različiti stupnjevi i vrste sudova; poslovni red suda; stranke u parnici; tužbe i prigovori), drugi dio parnično suđenje (redovito parnično suđenje; usmeni parnični postupak), treći dio određe-

57 O čl. 6. st. 3. Ugovora o dušobrižništvu katoličkih vjernika, pripadnika oružanih snaga i redarstvenih službi Republike Hrvatske vidi Eterović, op. cit. u bilj. 1, str. 283 - 284, s poredbenim referencijama.

58 Cjelovitu obradu VI. knjige CIC-a pružio je Škalabrin, N., Kaznene mjere u Crkvi, Đakovo, 2004.; usporedi i Svažić, E., Kažnjiva djela, kaznene mjere i kazneni postupak u Crkvi, Riječki teološki časopis, vol. 38, , br. 2, 2012., str. 335 - 352. 
ne posebne postupke (ženidbeni postupci, parnice za proglašenje ništavosti svetoga ređenja, načini izbjegavanja suđenja), četvrti dio kazneni postupak, dok peti dio sadržava odredbe o postupku u upravnim utocima i o postupku u uklanjanju ili premještanju župnika. Treba odmah istaknuti da postoji i relevantan broj djela na hrvatskom jeziku o pravnim materijama VII. knjige. 59 Što se laika tiče, najznačajniji su i najčešći od svih navedenih postupaka ženidbeni postupci. Stoga u kontekstu VII. knjige CIC-a treba, primjerice, shvatiti i značenje čl. 13. st. 4. Ugovora o pravnim pitanjima, koji određuje da se odluke crkvenih sudova o ništavosti ženidbe i odluke Vrhovne vlasti Crkve o razrješenju ženidbenog veza dostavljaju nadležnome državnom sudu radi primjene građanskih učinaka odluke, u skladu s odredbama zakonodavstva Republike Hrvatske. ${ }^{60}$ Premda navedena odredba u biti ovlašćuje crkvene sudove dostaviti navedene svoje odluke nadležnom državnom sudu radi primjene građanskih učinaka takvih odluka, crkveni sudovi do sada nisu tako postupali. Stoga je u jednom slučaju sama zainteresirana stranka podnijela "Prijedlog radi priznanja strane sudske odluke te upisa primjene građanskopravnih učinaka ništavosti kanonske ženidbe", koji je nadležni Općinski sud prihvatio te donio rješenje kojim se priznaje presuda nadležnog ženidbenog suda kojom je utvrđena ništavost kanonske ženidbe, uz obrazloženje da je presuda kojom je utvrđena ništavost kanonske ženidbe donesena u ime Svete Stolice, odnosno od ženidbenog suda kao suda strane države te da ne postoje negativne pretpostavke za priznanje strane sudske odluke iz čl. 88. do 92. Zakona o rješavanju sukoba zakona s propisima drugih zemalja u određenim odnosima (Narodne novine,

59 Cjelovitu obradu VII. knjige CIC-a pružio je također Škalabrin, N., Postupci, Đakovo, 2000.; vidi i Šalković, J. (ur.), Ništavost ženidbe: procesne i supstantivne teme, Zbornik radova II. znanstvenog simpozija crkvenih pravnika s međunarodnim sudjelovanjem, Zagreb, 2009.; Šalković, J. (ur.), Posebni sudski postupci i postupanja, Zbornik radova Međunarodnog znanstvenog simpozija crkvenih pravnika u Lovranu 26. - 27. X. 2009., Zagreb, 2010.; Šalković, J. (ur.), Strukturalne pretpostavke sudske vlasti u Crkvi, Zbornik radova V. međunarodnog znanstvenog simpozija crkvenih pravnika u Zadru, 21. - 22. listopada 2011., Zagreb, 2012.; Boljat, L.; Šalković, J., Priručnik za provedbu pastoralne istrage i pripremu parnice proglašenja ništavosti ženidbe, Zagreb, 2016.; Zec, S., Mitis Iudex Dominus Iesus. Blagi sudac Gospodin Isus. Komentar i primjena, Zagreb, 2017.

O građanskim učincima odluka crkvenih sudova u komparativnom kontekstu vidi Eterović, op. cit. u bilj. 1, str. 186 - 189; usporedi i Hrabar, D., Poništaj braka-prijepori kanonskog i obiteljskopravnog pogleda, u: Šalković, J. (ur.), Ništavost ženidbe: procesne i supstantivne teme, Zbornik radova II. znanstvenog simpozija crkvenih pravnika s međunarodnim sudjelovanjem, Zagreb, 2009., str. 37 - 56; Hlača, N., Prestanak braka u aktualnoj pravnoj problematici - odnos kanonskog i civilnog prava. Usporedba stanja u Republici Hrvatskoj $i$ Republici Italiji, Riječki teološki časopis, vol. 10, br. 1, 2002., str. 57 - 79. 
br. 73/1991). ${ }^{61}$ Promatrajući navedenu presudu, koja bi svakako zahtijevala produbljenu poredbenu raščlambu, ipak moramo istaknuti kako smatramo da Ugovor o pravnim pitanjima, u čl. 13., nije imao namjeru tretirati kanonsku ženidbu institutom stranog prava, a crkvene sudove sudbenim tijelima strane države. O tome svjedoči i volja hrvatskog zakonodavca, izražena i u čl. 47. st. 4. Obiteljskog zakona, koji određuje da ako brak sklopljen u vjerskom obliku prestane poništajem ili razvodom kad odluka državnog suda o poništaju ili razvodu braka postane pravomoćna, "prestanak braka ne utječe na obveze bračnih drugova koje proizlaze iz propisa vjerske zajednice pred kojom je brak sklopljen". ${ }^{62}$ Osim toga, notorna je činjenica da Sveta Stolica nije država, pa ni crkveni sudovi koji donose odluke u njezino ime nisu državni sudovi, a kamoli "sud strane države". Sve bi to moglo voditi ka zaključku da kako spomenuti međunarodni ugovor, tako i hrvatsko zakonodavstvo, zapravo tretiraju kanonsku ženidbu kao institut nedržavnog prava, a crkvene sudove kao nedržavne sudove nadležne za ženidbene postupke, koji, međutim, analogno različitim ugovorima nereguliranim državnim propisima ili arbitražnim sudovima kao nedržavnim sudovima, imaju svoje mjesto unutar hrvatskog pravnog sustava, a ne izvan njega. Osim materije ženidbenih postupaka, koja ne gubi na svojoj aktualnosti, u posljednje se vrijeme čini da u kontekstu interakcije VII. knjige CIC-a i državnog pravnog poretka posebice može postati značajna materija kaznenog postupka. U tom smislu ponajprije treba napomenuti da je 2013. Hrvatska biskupska konferencija usvojila Smjernice za postupanje u slučajevima spolnog zlostavljanja maloljetnika od strane klera, odobrene 2015. od strane Kongregacije za nauk vjere ${ }^{63}$, koje, među ostalim, nakon apostrofiranja "neovisnosti kanonskog i državnog kaznenog postupka" (t. 6.), određuju potrebu "suradnje s državnim vlastima" (t. 7.). U kontekstu te suradnje posebice je određeno sljedeće: "Budući da se kazneno djelo spolnoga zlostavljanja i iskorištavanja djeteta progoni po službenoj dužnosti, neka Ordinarij obavijest o kažnjivome djelu oprezno ispita i ustanovi je li obavijest vjerodostojna. Nakon toga, shodno pozitivnim državnim propisima Republike Hrvatske, te pazeći da "ne dođe u pogibelj dobar glas bilo koga” (kan. 1717. § 2.), neka se na prikladan način podnese prijava državnim

${ }_{61}$ Vidi Rješenje Općinskog suda u Novom Zagrebu, stalna služba u Zaprešiću, 38 R191/16-2, od 4. svibnja 2016. godine.

62 Usporedi Eterović, op. cit. u bilj. 1, str. 191 - 193.

63 Tekst navedenih Smjernica dostupan je na internetskoj stranici HBK-a: http://hbk.hr/ dokumenti-hbk/smjernice-za-postupanje-u-slucajevima-spolnoga-zlostavljanja-maloljetnika-od-strane-klerika (20. srpnja 2020.). 
vlastima, osim ako se istraživanje čini posve suvišnim (usp. kan. 1717. § 1.)”. ${ }^{64}$ Premda mysterium iniquitatis u obliku spolnog zlostavljanja maloljetnika od strane klera nije u našem podneblju, na veliku sreću, dosegao ni izbliza takve razmjere kao u nekim drugim zapadnim državama, nije teško zaključiti da bi određene kanonske odredbe u navedenom kontekstu mogle biti - na temelju suradnje Crkve s državne vlastima - relevantne i za hrvatsku sudsku praksu. No, nadajmo se da će broj takvih slučajeva biti što bliže ništici.

\section{3. "PREMA ODREDBAMA KANONSKOGA PRAVA I ZAKONODAVSTVA REPUBLIKE HRVATSKE": KAKO POSTUPITI U SLUČAJEVIMA NESUGLASNOSTI DVAJU PRAVNIH SUSTAVA?}

Četiri ugovora sa Svetom Stolicom na više mjesta predviđaju da će se određeni pravni odnos urediti prema odredbama kanonskog prava i zakonodavstva Republike Hrvatske. Vjerojatno je u praktičnom smislu najznačajnija takva norma već spomenuti čl. 10. st. 1. Ugovora o pravnim pitanjima, koji određuje da "crkvene pravne osobe mogu kupovati, posjedovati, koristiti ili otuđivati pokretna i nepokretna dobra, te stjecati i otuđivati imovinska prava, prema odredbama kanonskoga prava i zakonodavstva Republike Hrvatske", no identično ili podudarno rješenje o primjeni obaju pravnih sustava predviđeno je i glede nekolicine drugih pravnih materija. ${ }^{65}$ Budući da su Sveta Stolica i Republika Hrvatska kao međunarodni subjekti u svemu ravnopravne strane tih četiriju međunarodnih ugovora, isključena je unaprijed mogućnost da u kontekstu normativnog izričaja "prema odredbama kanonskoga prava i zakonodavstva Republike Hrvatske" jedan od tih dvaju pravnih izvora bude hijerarhijski nadređen drugome s aspekta pravne snage. No ta hijerarhijska izjednačenost neće naravno vrijediti u slučaju ako je riječ o podzakonskoj razini propisa. U tom kontekstu postavlja se još jedno pitanje. Ako su u konkretnom slučaju odredbe kanonskoga prava s jedne strane te zakonodavstva Republike Hrvatske s druge strane međusobno sukladne ili se međusobno neprijeporno nadopunjuju, pro-

64 O navedenoj problematici vidi Pleić; Vukušić, op. cit. u bilj. 49, str. 762 - 767, s uputama na daljnju relevantnu literaturu.

65 Usporedi npr. i čl. 13. st. 4. (kanonska ženidba), čl. 15. st. 1. (osnivanje i upravljanje obrazovnim ustanovama) Ugovora o pravnim pitanjima; čl. 3. st. 1. (katolički vjeroučitelji), čl. 7. st. 1. (održavanje vjeronauka), čl. 8. st. 1. (osnivanje i upravljanje katoličkim školama), čl. 12. st. 2. (crkvena sredstva društvenog priopćavanja) Ugovora o suradnji na području odgoja i kulture; čl. 6. st. 2. (služba djelatnika Vojnog ordinarijata) Ugovora o dušobrižništvu katoličkih vjernika, pripadnika oružanih snaga i redarstvenih službi Republike Hrvatske itd. 
blema u primjeni dvaju različitih pravnih sustava na istu pravnu situaciju neće biti. No kako postupiti u slučaju ako su odredbe tih dvaju pravnih sustava o istoj materiji međusobno različite ili čak suprotstavljene?

Pokušajmo raščlaniti navedeni problem na jednom konkretnom slučaju. Hrvatski Zakon o vlasništvu i drugim stvarnim pravima (dalje u tekstu: ZV) ${ }^{66} \mathrm{u}$ čl. 159. st. 4. određuje da će "samostalni posjednik stvari u vlasništvu Republike Hrvatske, županija i jedinica lokalne samouprave i jedinica lokalne samouprave i uprave i s njima izjednačenih pravnih osoba, kao i stvari u vlasništvu crkve ili drugih pravnih osoba koje ne traže za sebe dobitak nego služe za dobrotvorne ili druge općekorisne svrhe, steći dosjelošću vlasništvo tih stvari tek pošto je njegov zakonit, istinit i pošten, ili barem pošten, samostalni posjed neprekidno trajao dvostruko vrijeme" od inače predviđenog roka. ${ }^{67}$ Tako bi se, primjerice, prema navedenoj odredbi, nekretnine u vlasništvu Crkve mogle steći izvanrednom dosjelošću tek nakon četrdeset godina neprekinutog posjedovanja ${ }^{68}$ Navedene povlastice ili privilegija u korist Crkve nije naravno bilo u komunističkim propisima. Međutim, interesantno je u ovom kontekstu napomenuti da je ta povlastica, čak i glede duljine roka, danas iznova istovjetna s quadraginta annorum praescriptio kojom je još car Justinijan svojim propisima privilegirao crkve, samostane ili pobožne zaklade glede stvari u njihovu vlasništvu.

Kako bismo bolje razumjeli odakle potječu razlike u ovoj materiji između hrvatskog pravnog sustava s jedne strane te kanonskog prava s druge strane, nužno je u nekoliko rečenica prikazati Justinijanovo zakonodavstvo glede navedene problematike. Spomenuti latinski izraz quadraginta annorum praescriptio odnosi se na dvije Justinijanove Novele (Novella 111, 1. iz 541. godine te Novella 131, 6. iz 545. godine) prema kojima pošteni posjednik (possessor bonae fidei) $\mathrm{u}$ okviru izvanredne dosjelosti (longissimi temporis praescriptio), tj. bez valjanog pravnog temelja (iusta causa), može steći stvari u vlasništvu crkava, samostana ili pobožnih zaklada tek nakon isteka roka od četrdeset godina (quadraginta annorum). Navedenim odredbama privilegirane su crkvene institucije jer je rok izvanredne dosjelosti u navedenom slučaju glede stvari u vlasništvu svih ostalih subjekata istjecao nakon 30 godina. Justinijan je isprva u jednoj konstituciji iz 530. godine odredio da rok za izvanrednu dosjelost glede stvari u crkvenom

66 Narodne novine, br. 91/1996, 68/1998, 137/1999, 22/2000, 73/2001, 114/2001, 79/2006, 141/2006, 146/2008, 38/2009, 153/2009, 143/2012, 152/2014.

$67 \mathrm{O}$ čl. 159. st. 4. ZV-a vidi npr. Gavella, N. et al., Stvarno pravo, Zagreb, 1998., str. $412-418$.

68 Premda ZV u navedenoj odredbi govori o "crkvi" u jednini, mislimo da bi se navedena odredba trebala analogno primijeniti i na ostale vjerske zajednice koje imaju taj status prema Zakonu o pravnom položaju vjerskih zajednica. 
vlasništvu iznosi čak 100 godina (Codex Iustinianus 1, 2, 23 te 7, 40, 1), da bi spomenutim dvjema Novelama bio smanjen na 40 godina. ${ }^{69}$ Prema novijim spoznajama, dotično skraćenje nije se, međutim, odnosilo i na Rimsku Crkvu, za koju je i nadalje, na temelju Justinijanove Novele 9. iz 535. godine, vrijedio stogodišnji rok. ${ }^{70}$ Što se, pak, hrvatskog stvarnog prava tiče, treba napomenuti da je navedena odredba o povlasticama za Crkvu kod izvanredne dosjelosti, s najduljim rokom od 40 godina, unesena u čl. 159. st. 4. ZV-a po uzoru na $\S$ 1472 ABGB-a/OGZ-a. Premda ćemo, kako u navedenom paragrafu ABGB-a/ OGZ-a, tako i u navedenoj odredbi ZV-a, naići na pojedina rješenja koja se u određenim detaljima razlikuju od Justinijanove regulacije, mora se istaknuti da je sama ratio postojanja takvih povlastica ostala do danas nepromijenjena. ${ }^{71}$

Kako navedene rokove regulira važeće kanonsko pravo? Načelno gledano, kako u pogledu dosjelosti kojom se stječe neko pravo (usucapio ili praescriptio acquisitiva), zastare kojom se gubi neko pravo (praescriptio exstinctiva) i zastare koja oslobađa od neke obveze (praescriptio liberativa) ${ }^{72}$, kanonsko pravo određuje kanonizaciju civilnog zakonodavstva (usporedi CIC, kan. 197.; CCEO, kan. 1540. ${ }^{73}$, uz posebne odredbe glede određenih pravnih subjekata i/ili objekata koje predviđaju kako CIC, tako i CCEO. Koje su to posebne odredbe? S jedne strane, CIC u svojem kan. 1270. određuje da "nekretnine, pokretne dragocjenosti, prava i tužbe, bilo osobne bilo stvarne, koje pripadaju Apostolskoj Stolici, zastarijevaju u roku od sto godina; ako pripadaju drugoj crkvenoj javnoj pravnoj osobi, zastarijevaju u roku od trideset godina". ${ }^{74} \mathrm{~S}$ druge strane, CCEO - koji se

69 O navedenoj povlastici u korist Crkve vidi npr. Kaser, M., Das römische Privatrecht, 2. Abschnitt: Die nachklassischen Entwicklungen, München, 1975., str. 287 - 288, s uputama na daljnju literaturu.

70 O toj povlastici za Rimsku Crkvu vidi detaljnije Kaiser, W., Zur hundertjährigen Verjährung zugunsten der römischen Kirche, Zeitschrift der Savigny-Stiftung für Rechtsgeschichte (Kanonistische Abteilung), br. 85, 1999., str. 60 - 103.

71 O § 1472 ABGB-a vidi npr. Mader, P., u: Schwimann, M. (ed.), Praxiskommentar zum $A B G B, B d$. 7, $\S \S 1293-1502$ ABGB, Wien, 1997., str. $704-705$.

72 O različitim vrstama preskripcije (praescriptio) u kanonskom pravu, uz napomenu da navedena klasifikacija ima podrijetlo u općem pravu (ius commune), vidi npr. Brkan, J., Zastara (praescriptio) u kanonskom i građanskom pravu, Crkva u svijetu, vol. 38, br. 3, 2003., str. 373 - 379.; Škalabrin, N., Stjecanje dobara, Bogoslovska smotra, vol. 75, br. 1, 2004., str. 244 - 246, s uputama na daljnju literaturu.

73 O kanonizaciji civilnih zakona u navedenom kontekstu vidi Brkan, op. cit. u bilj. 72, str. 375 - 381; Škalabrin, op. cit. u bilj. 72, str. 246; općenito o kanonizaciji vidi supra pod 1.

74 Can. 1270: "Res immobiles, mobiles pretiosae, iura et actiones sive personales sive reales, quae pertinent ad Sedem Apostolicam, spatio centum annorum praescribun- 
primjenjuje i u Hrvatskoj u pogledu grkokatoličke Križevačke eparhije - određuje u svojem kan. 1019. sljedeće: "Nekretnine, pokretne dragocjenosti, to jest one koje su od velikog povijesnog, umjetničkog ili materijalnog značenja, prava i tužbe, bilo osobne bilo stvarne, koje pripadaju Apostolskoj Stolici, zastarijevaju u roku od sto godina; ako pripadaju kojoj samosvojnoj Crkvi ili eparhiji, zastarijevaju u roku od pedeset godina, a ako pripadaju drugoj pravnoj osobi, zastarijevaju u roku od trideset godina". ${ }^{75}$ Kako vidimo, u našem konkretnom slučaju instituta dosjelosti, ne samo da glede rokova dosjelosti na crkvenim stvarima postoji razlika između hrvatskog pravnog sustava i kanonskog prava, nego još dodatno postoji i razlika između kanonskog prava latinske Crkve i kanonskog prava istočnih Crkava. Kako je onda u takvoj situaciji uopće moguće riješiti konkretan slučaj "prema odredbama kanonskoga prava i zakonodavstva Republike Hrvatske"?

Prema odredbama citiranog čl. 159. st. 4. hrvatskog ZV-a, rok dosjelosti na crkvenim stvarima trajao bi "dvostruko vrijeme" od inače predviđenog roka. To konkretno znači da bi rok redovite dosjelosti - tj. dosjelosti kod koje je samostalan posjed zakonit (possessio iusta), istinit (possessio non vitiosa) i pošten (possessio bonae fidei) - iznosio na crkvenim pokretninama šest godina, a na crkvenim nekretninama dvadeset godina. Rok izvanredne dosjelosti - tj. dosjelosti kod koje je samostalan posjed barem pošten (possessio bonae fidei) - iznosio bi na crkvenim pokretninama dvadeset godina, a na crkvenim nekretninama već spomenutih justinijanskih četrdeset godina. ${ }^{76}$ Navedeno civilno uređenje instituta dosjelosti je, kako smo vidjeli, "kanonizirano" odredbama kanonskog prava, no uz određene posebnosti. Takve posebne odredbe su dvojake: one se odnose i na određene pravne subjekte, i na određene pravne objekte. Pravni objekti, na koje se glede dosjelosti neće primjenjivati "kanonizirane" odredbe civilnog prava, već posebne odredbe kanonskog prava, jesu nekretnine i dragocjene pokretnine. ${ }^{77} \mathrm{U}$ pogledu

tur; quae ad aliam personam iuridicam publicam ecclesiasticam pertinent, spatio triginta annorum".

75 CCEO, Can. 1019: "Res immobiles, res mobiles pretiosae, quae scilicet magni sunt momenti artis vel historiae vel materiae causa, iura et actiones sive personales sive reales, quae pertinent ad Sedem Apostolicam, spatio centum annorum praescribuntur; quae ad aliquam Ecclesiam sui iuris vel eparchiam pertinent, spatio quinquaginta annorum, quae vero ad aliam personam iuridicam, spatio triginta annorum".

76 ZV, čl. 159., st. 1. - 4. O navedenim odredbama ZV-a, posebice o razlici između redovite i izvanredne dosjelosti vidi npr. Gavella et al.., , op. cit. u bilj. 67, str. $410-418$.

77 Usporedi Brkan, op. cit. u bilj. 72, str. 381 - 384, 387 - 388; Škalabrin, op. cit. u bilj. 72, str. 247. Kako vidimo, pojam dragocjenih pokretnina (mobiles pretiosae) nije normiran u CIC-u, no njihovu definiciju sadrži CCEO, kan. 1019., određujući ih kao pokretnine "od velikog povijesnog, umjetničkog ili materijalnog značenja” (quae 
pravnih subjekata, ako je vlasnik navedenih dviju vrsta stvari Apostolska Stolica (tj. Sveta Stolica), rok dosjelosti iznosi čak 100 godina (spatio centum annorum) (CIC, kan. 1270.; CCEO, kan. 1019.). ${ }^{78}$ Kako vidimo, navedeni kanoni i danas nedvojbeno slijede spomenutu Justinijanovu Novelu 9. iz 535. godine, prema kojoj je Rimska Crkva privilegirana sa stogodišnjim rokom. U latinskoj Crkvi rok dosjelosti za stvari u vlasništvu crkvenih javnih pravnih osoba iznosi trideset godina (spatio triginta annorum) (CIC, kan. 1270.), dok u istočnim Crkvama rok dosjelosti za stvari u vlasništvu samosvojne crkve ili eparhije - kakva je npr. Križevačka eparhija u Hrvatskoj - iznosi pedeset godina (spatio quinquaginta annorum), a za stvari u vlasništvu drugih crkvenih pravnih osoba trideset godina (spatio triginta annorum). ${ }^{79}$ Navedene nesuglasnosti glede trajanja rokova dosjelosti između hrvatskog pravnog sustava i kanonskog prava najlakše ćemo uskladiti ako citirane odredbe kanonskog prava o posebnim rokovima dosjelosti za određene pravne subjekte i pravne objekte shvatimo kao lex specialis spram općeg uređenja hrvatskog stvarnog prava. Takvim tumačenjem - utemeljenim na općem načelu prava lex specialis derogat legi generali, kojim se rješavaju antinomije u pravnom sustavu na osnovi kriterija specijalnosti (posebnosti) ${ }^{80}-$ mogli bi se konkretni slučajevi dosjelosti na stvarima u vlasništvu Crkve doista riješiti "prema odredbama kanonskoga prava i zakonodavstva Republike Hrvatske" na sustavan način.

Međutim, smatramo da u konkretnom slučaju nije dostatno tek shvatiti pojedine crkvene kanone kao lex specialis. To može biti rješenje u velikoj većini konkretnih slučajeva, ali možda i ne baš u svakom od njih. Na što točno pri tome mislimo? Kako smo vidjeli, navedena pravila o rokovima dosjelosti predstavljaju još od cara Justinijana po svojoj pravnoj naravi povlasticu ili privilegij

scilicet magni sunt momenti artis vel historiae vel materiae causa). Navedena definicija oslanja se na CIC 1917., kan. 1497. § 2., koji određuje dragocjene pokretnine kao one koje imaju neku značajnu vrijednost zbog umjetničkog, povijesnog ili materijalnog razloga (pretiosa, quibus notabilis valor sit, artis vel historiae vel materiae causa); usporedi Škalabrin, op. cit. u bilj. 72, loc. cit.

78 Vidi Brkan, op. cit. u bilj. 72, str. 381 - 383, 387 - 388; Škalabrin, op. cit. u bilj. 72, str. 247.

79 Pri tome se ne smije izgubiti iz vida jedna razlika: CIC u navedenom kontekstu govori samo o "drugim crkvenim javnim pravnim osobama”, dok CCEO govori općenito o "drugim pravnim osobama", ne razlikujući javne i privatne osobe (usporedi i CCEO, kann. 921. i 1009., § 2.). Tome nasuprot, Ugovor o pravnim pitanjima (čl. 2. st. 1. - 2.) poznaje navedenu razliku; vidi supra, s uputama na daljnju literaturu.

80 Usporedi Brkan, op. cit. u bilj. 72 str. 380, bilj. 18; o općem načelu lex specialis derogat legi generali usporedi npr. Petrak, M., Traditio iuridica, (vol. I.): Regulae iuris, Zagreb, 2010., str. $79-80$. 
za Crkvu. No ako detaljno promotrimo izložene norme, moguće je predvidjeti situaciju u kojoj bi rok dosjelosti po kanonskom pravu za nekretninu u vlasništvu određene crkvene pravne osobe iznosio trideset godina, dok bi isti rok po hrvatskom zakonodavstvu iznosio četrdeset godina. Štoviše, teorijski je čak zamisliva i situacija u kojoj bi u kontekstu latinske Crkve određena nekretnina bila u suvlasništvu jedne crkvene javne pravne osobe i jedne crkvene privatne pravne osobe. Dok bi rok dosjelosti, ako bi se CIC, kan. 1270. shvatio kao norma specialis, glede javne pravne osobe iznosio trideset godina, isti bi rok glede privatne pravne osobe, budući da je za nju i po kanonskom pravu mjerodavno hrvatsko zakonodavstvo, iznosio četrdeset godina! Nije teško zaključiti da bi u takvoj situaciji striktna primjena načela lex specialis derogat legi generali, osim sasvim "necrkvenog" privilegiranja privatnog nad javnim ${ }^{81}$, dovela u pitanje i samu pravnu narav navedene povlastice ili privilegija "duljeg roka" dosjelosti na crkvenoj imovini. Kako se u takvoj situaciji ne bi pravno obesmislilo samo postojanje takve povlastice ili privilegija, smatramo da se u dvije opisane situacije mora iznimno napustiti načelo lex specialis derogat legi generali te sukladno samoj pravnoj naravi instituta, koristeći se ciljnim (teleološkim) tumačenjem, u svakom takvom konkretnom slučaju primijeniti one odredbe koje predviđaju dulji rok dosjelosti.

Treba napomenuti da provedena kratka raščlamba predstavlja tek "predokus" pravne kompleksnosti na kakvu možemo naići u "međuzemlju” između kanonskog prava i hrvatskog pravnog sustava te zorno svjedoči o činjenici da će adekvatnu primjenu četiriju ugovora između Svete Stolice i Republike Hrvatske u pojedinim situacijama biti moguće postići tek na temelju primjerenog znanja o "odredbama kanonskoga prava i zakonodavstva Republike Hrvatske" i određenog poduzetog napora u pravnom mišljenju.

\section{ZAKLJUČNE NAPOMENE}

U prethodnoj raščlambi istražili smo međusobni odnos kanonskog prava kao pravnog sustava Katoličke Crkve, kojoj pripada najveći broj hrvatskih građana, i hrvatskog pravnog sustava, usredotočivši se na problematiku kanonskog prava (ius canonicum) kao izvora prava u hrvatskom pravnom sustavu na temelju konkordatskog prava (ius concordatarium): četiriju međunarodnih ugovora između

${ }_{81}$ Usporedi npr. CIC, kan. 116. § 1., koji ističe kako javne pravne osobe (personae iuridicae publicae), za razliku privatnih pravnih osoba (personae iuridicae privatae), izvršavaju svoju zadaću u ime Crkve radi općeg dobra (bonum publicum); o navedenoj odredbi vidi npr. Brkan, J., Opće odredbe, op. cit. u bilj. 16, str. $206-208$. 
Svete Stolice i Republike Hrvatske. Pri tome se, što se kanonskog prava tiče, iz razumljivih razloga ograničilo na njegov najvažniji izvor: Zakonik kanonskog prava (Codex Iuris Canonici - CIC) iz 1983., tu nedvojbeno najvažniju religijsku pravnu kodifikaciju u svjetskim razmjerima.

Slijedeći sustav CIC-a po pojedinim knjigama od ukupno sedam, ukratko se raščlanilo pojedinačne odredbe navedenih međunarodnih ugovora koje su uvele u hrvatski pravni sustav čitav niz instituta i odredaba kanonskog prava kao važeći normativni sadržaj. Osim toga, zaključeno je da CIC predstavlja relevantni konceptualni i normativni zajednički okvir za sve odredbe međunarodnih ugovora između Svete Stolice i Republike Hrvatske koje se pozivaju na kanonsko pravo ili na pojedine njegove institute. Točnije rečeno, kada se temeljitije raščlane pojedine odredbe međunarodnih ugovora između Svete Stolice i Republike Hrvatske, nije teško zaključiti da je zapravo, na temelju navedenih odredaba, CIC kao cjelina postao relevantan izvor prava u hrvatskom pravnom sustavu. Također, tijekom navedene analize, uputilo se na relevantnu hrvatsku kanonističku literaturu o problematici koja se prikazivala, a posebice se osvrnulo na postojeću judikaturu hrvatskih državnih sudova glede pojedinih kanona CIC-a, ističući kako dobre primjere takve primjene odredaba kanonskog prava, tako i kritički raščlanjujući pojedine slučajeve u kojima sudovi nisu ponajbolje shvatili te primijenili pojedine aspekte kanonskog prava. Osim toga, posebno je raščlanjeno pitanje kako postupiti u slučajevima u kojima spomenuti međunarodni ugovori propisuju da se na određenu pravnu materiju kumulativno trebaju primijeniti “odredbe kanonskoga prava i zakonodavstva Republike Hrvatske" te kako u tom kontekstu riješiti moguće nesuglasnosti između tih dvaju pravnih sustava.

Sve u svemu, na temelju navedenog istraživanja, može se zaključno istaknuti da značenje kanonskog prava, osobito CIC-a kao njegova najvažnijeg izvora, u hrvatskom pravnom sustavu u posljednjih četvrt stoljeća nedvojbeno postaje sve veće, a time nužno raste i potreba za njegovim produbljenim poznavanjem, kako od strane pravne doktrine, tako i sudske prakse. 


\section{LITERATURA}

Baćak, A. A. (ur.), Novo pravo ustanova posvećenoga života. Zbornik radova Desetog redovničkog tjedna, Zagreb, 1991.

Berljak, M., Iter i glavne značajke novog Kodeksa kanonskog prava, Bogoslovska smotra, vol. 54, br. 2-3, 1984., str. 234-254.

Berljak, M., Kanonski oblik ženidbe. Povijesni razvoj-Zakonik kanonskoga prava/1983., Zagreb, 1999.

Berljak, M., Kumovi- svjedoci. Krst - Potvrda - Ženidba, Zagreb, 2010.

Berljak, M., Novi crkveni Zakonik - Kodeks kanonskoga prava Ivana Pavla II. - Nastajanje - proglašenje - stupanje na snagu - sadržaj, Bogoslovska smotra, vol. 53, br. 2-3, 1983., str. 165-182.

Berljak, M., Položaj i djelovanje Katoličkoga bogoslovnog fakulteta u sastavu Sveučilišta u Zagrebu. Dvadeseta obljetnica potpisivanja Ugovora, Bogoslovska smotra, vol. 86, br. 1, 2016., str. 31-65.

Berljak, M., Sakramenti ozdravljenja. Pokora i bolesničko pomazanje: pravno-pastoralni komentar, Zagreb, 2004.

Berljak, M., Zakonik crkvenog prava, uređen po odredbi pape Pija X., proglašen po nalogu pape Benedikta XV. (1917.). Dr. Josip Pazman (1863.-1925.), Zagreb/ Rim, 2014.

Blažević, V., Crkveni partikularni sabori i dijecezanske sinode na području Hrvatske i drugih južnoslavenskih zemalja, Zagreb, 2012.

Blažević, V., Ženidbeno pravo Katoličke crkve. Pravno-pastoralni priručnik, Zagreb, 2004.

Blažević, V., Župe i župnici. Pravno-pastoralni repetitorij, Zagreb, 2014.

Boljat, L.; Šalković, J., Priručnik za provedbu pastoralne istrage i pripremu parnice proglašenja ništavosti ženidbe, Zagreb, 2016.

Brkan, J., Crkvena vremenita dobra. Temeljni kanoni i upravljanje dobrima, Split, 2006.

Brkan, J., Klerici u zakonodavstvu Katoličke Crkve, Split, 2012.

Brkan, J., Neke razlike u zakonicima latinske Crkve i istočnih Katoličkih Crkava, Služba Božja, vol. 54, br. 1, 2014., str. 5-34.

Brkan, J., Obveze i prava vjernika laika, Split, 2005.

Brkan, J., Opće odredbe Zakonika kanonskog prava, Makarska, 1997.

Brkan, J., Ugovori i napose otudenje (kan. 1290-1298), Služba Božja, vol. 45, br. 2, 2004., str. 8-37.

Brkan, J., Ustanove posvećenoga života i družbe apostolskoga života prema Zakoniku kanonskoga prava, Šibenik, 2007. 
Brkan, J., Zastara (praescriptio) u kanonskom i građanskom pravu, Crkva u svijetu, vol. 38, br. 3, 2003., str. 373-389.

Brkan, J., Župa u zakonodavstvu Katoličke crkve, Split, 2004.

Codex Canonum Ecclesiarum Orientalium fontium annotatione auctus/Zakonik kanona istočnih Crkava s izvorima, Zagreb, 1996.

Codex Iuris Canonici fontium annotatione auctus MDCCCCXVII/Kodeks kanonskog prava s izvorima 1917. (preveo Franjo Herman), Zagreb, 2007.

Codex Iuris Canonici fontium annotatione auctus/Zakonik kanonskog prava s izvorima, Zagreb, 1996.

Eterović, N., Ugovori između Svete Stolice i Republike Hrvatske (povijest nastanka $i$ komentar), Zagreb, 2001.

Eterović, N., Ugovori između Svete Stolice i Republike Hrvatske, Crkva u svijetu, vol. 32, br. 2, 1997., str. 181-186.

Gavella, N. et al., Stvarno pravo, Zagreb, 1998.

Hlača, N., Prestanak braka u aktualnoj pravnoj problematici-odnos kanonskog i civilnog prava. Usporedba stanja u Republici Hrvatskoj i Republici Italiji, Riječki teološki časopis, vol. 10, br. 1, 2002., str. 57-79.

Hrabar, D., Poništaj braka - prijepori kanonskog i obiteljskopravnog pogleda, u: Šalković, J. (ur.), Ništavost ženidbe: procesne i supstantivne teme, Zbornik radova II. znanstvenog simpozija crkvenih pravnika s međunarodnim sudjelovanjem, Zagreb, 2009., str. 37-56.

Ivanišević, G., Marčanska unija 1611. i Križevačka eparhija 1777. Ljetopis i pojmovnik, Zagreb, 2018.

Jakulj, I., Pravni položaj Katoličke Crkve u Republici Hrvatskoj: od totalitarizma do demokracije, Crkva u svijetu, vol. 50, br. 3, 2015., str. 478-513.

Kaiser, W., Zur hundertjährigen Verjährung zugunsten der römischen Kirche, Zeitschrift der Savigny-Stiftung für Rechtsgeschichte (Kanonistische Abteilung), vol. 85, 1999., str. 60-103.

Kaser, M., Das römische Privatrecht, 2. Abschnitt: Die nachklassischen Entwicklungen, München, 1975.

Manjgotić, J., Temeljne postavke i ustroj novog Zakonika, Svesci. Časopis Centra za koncilska istraživanja, dokumentaciju i informacije "Kršćanska sadašnjost", vol. 14, br. 51, 1983., str. 17-24.

Mikulić, E.; Šalković, J., Pravo i načela pristupa „medijskom prostoru“ prema ugovorima između Svete Stolice i Republike Hrvatske, u: Valković, J. (ur.), Vjerska tematika u hrvatskom medijskom prostoru. Zbornik radova znanstvenog simpozija i projekta na Hrvatskom katoličkom sveučilištu u Zagrebu, Zagreb, 2019., str. 13-28. 
Milotić, I., Radni odnos i kanonski mandat u RH - u povodu jedne presude europskog suda za ljudska prava u Strasbourgu, Pravo i porezi, br. 11, 2016., str. 17-23.

Petrak, M., Kanonsko pravo i hrvatski pravni sustav (I). Pravni izvori i pravna načela, Zbornik Pravnog fakulteta u Zagrebu, vol. 70, br. 2-3, 2020., str. 251-286.

Petrak, M., Traditio iuridica, vol. I: Regulae iuris, Zagreb, 2010.

Pleić, M.; Vukušić, I., Neka pitanja suradnje države i Katoličke Crkve u području kaznenog prava, Zbornik radova Pravnog fakulteta u Splitu, vol. 57, br. 3, 2020., str. 759-781.

Pranjić, P., Božji narod - II. knjiga ZKP-a, Sarajevo, 2012.

Pranjić, P., Posvetiteljska služba Crkve. Komentar 4. knjige ZKP-a, Zagreb, 2016.

Pranjić, P., Vremenita dobra i vremenita dobra u Crkvi, Zagreb, 2013.

Schwimann, M. (ed.), Praxiskommentar zum ABGB, Bd. 7, §§ 1293-1502 ABGB, Wien, 1997.

Staničić, F., Zabrana rada nedjeljom u trgovini - ustavnopravni aspekti, Informator, br. 6625, 2020., str. 12-15.

Svažić, E., Kažnjiva djela, kaznene mjere i kazneni postupak u Crkvi, Riječki teološki časopis, vol. 38, br. 2, 2012., str. 335-352.

Šalković, J., Katolička sveučilišta (kann. 807-814), Bogoslovska smotra, vol. 77, br. 4, 2008., str. 807-838.

Šalković, J., Obveze i prava vjernika laika (kann. 224-231). Poslanje i djelovanje, Zagreb, 2009.

Šalković, J., Pravni elementi evangelizacijskog poslanja Crkve. Komentar III. knjige Zakonika, Zagreb, 2013.

Šalković, J., Pravni okvir katoličkog vjeronauka u javnim školama: aktualnosti i perspektive, u: Razum, R. (ur.), Vjeronauk nakon dvadeset godina: izazov Crkvi i školi, Zbornik radova sa znanstvenog simpozija „Vjeronauk nakon dvadeset godina: izazov Crkvi i školi“, Zagreb, 2011., str. 121-141.

Šalković, J., Zakonik kanonskog prava - teološko-pravna sinteza Sabora, Bogoslovska smotra, vol. 75, br. 3, 2005., str. 767-792.

Šalković, J. (ur.), Ništavost ženidbe: procesne i supstantivne teme, Zbornik radova II. znanstvenog simpozija crkvenih pravnika s međunarodnim sudjelovanjem, Zagreb, 2009.

Šalković, J. (ur.), Posebni sudski postupci i postupanja, Zbornik radova Međunarodnog znanstvenog simpozija crkvenih pravnika u Lovranu 26. - 27. X. 2009., Zagreb, 2010.

Šalković, J. (ur.), Strukturalne pretpostavke sudske vlasti u Crkvi, Zbornik radova V. međunarodnog znanstvenog simpozija crkvenih pravnika u Zadru, 21. - 22. listopada 2011., Zagreb, 2012. 
Šalković, J. (ur.), Vjernici, društva, pokreti. Zbornik radova IV. međunarodnog znanstvenog simpozija crkvenih pravnika u Zagrebu, 29. - 30. listopada 2010., Zagreb, 2011.

Šalković, J. (ur.), Zakon u životu partikularne Crkve, Zbornik radova VIII. međunarodnog znanstvenog simpozija crkvenih pravnika u Trogiru - Čiovo, 9. - 10. listopada 2014., Zagreb, 2016.

Šalković, J. (ur.), Zaručništvo i priprava za ženidbu, Zbornik radova VII. međunarodnog znanstvenog simpozija crkvenih pravnika u Subotici, I1. - 12. listopada 2013., Zagreb, 2015.

Šanjek, F., Kakve nam mogućnosti crkvenog visokog školstva nude Ugovori RH i Svete Stolice, Riječki teološki časopis, vol. 5, br. 2, 1997., str. 295-301.

Škalabrin, N., Kanonska ženidba s građanskim učincima, Vjesnik Đakovačke i Srijemske biskupije, vol. 125, br. 3, 1997., str. 187-196

Škalabrin, N., Kaznene mjere u Crkvi, Đakovo, 2004.

Škalabrin, N., Postupci, Đakovo, 2000.

Škalabrin, N., Stjecanje dobara, Bogoslovska smotra, vol. 74, br. 1, 2004., str. 233-262.

Škalabrin, N., Ugovori i napose otuđenje (kann. 1290-1298), Bogoslovska smotra, vol. 76, br. 1, 2006., str. 137-199.

Škalabrin, N., Vremenita crkvena dobra, Đakovo, 2008.

Škalabrin, N., Ženidba. Pravno-pastoralni priručnik, Đakovo, 1995.

Wolter, U., Ius canonicum in iure civili. Studien zur Rechtsquellenlehre in der neueren Privatrechtsgeschichte, Köln/Wien, 1975.

Zec, S., Pravni temelji prisutnosti i djelovanja Crkve u javnosti u Republici Hrvatskoj, Riječki teološki časopis, vol. 36, br. 2, 2011., str. 387-412.

Zec, S., Mitis Iudex Dominus Iesus. Blagi sudac Gospodin Isus. Komentar i primjena, Zagreb, 2017.

Zovko, D., Viteštvo danas. Što je zbilja, što je fantazija?, Zagreb, 2016. 
Summary

\section{Marko Petrak*}

\section{CANON LAW AND THE CROATIAN LEGAL SYSTEM (II) CODEX IURIS CANONICI AND CONTEMPORARY CROATIAN LAW}

This article analyzes the relationship between canon law as the legal system of the Catholic Church, to which a majority of Croatian citizens belong, and the Croatian legal system, focusing on the issue of canon law (ius canonicum) as a source of law in the Croatian legal system on the basis of concordatarian law (ius concordatarium), i.e. the four international treaties between the Holy See and the Republic of Croatia. As regards canon law, in this contribution the author takes into account only its most important source: the Code of Canon Law (Codex Iuris Canonici-CIC) of 1983, the undoubtedly most important codification of religious law in the world.

Following the systematization of CIC into seven books, the author highlights particular provisions of the said treaties, which introduced into the Croatian legal system a series of institutes and provisions of canon law as binding normative contents. In addition, the author concludes that the Code represents a relevant conceptual and normative common framework for all provisions of the international treaties between the Holy See and the Republic of Croatia based on canon law or its institutes. To be more precise, a closer analysis of the provisions of the treaties between the Holy See and the Republic of Croatia leads to the conclusion that CIC has, in its totality, become a relevant source of law in the Croatian legal system. The author also refers to relevant Croatian scholarly literature on canon law, and in particular to the case-law of Croatian state courts which involves the application of certain canons of the Code, pointing out good examples of such application, and providing a critical view of particular cases in which, in the author's opinion, the courts made certain errors in the interpretation and application of some aspects of canon law.

Finally, the research suggests that the significance of canon law, particularly Codex iuris canonici as its primary source, in the Croatian legal system is undoubtedly increasing, which is why its deeper understanding both by legal doctrine and by the legal practice is becoming a necessity.

Keywords: canon law, Croatian law, Codex iuris canonici, concordatarian law, international treaties, case-law

* Marko Petrak, Ph. D., Professor, Faculty of Law, University of Zagreb, Trg Republike Hrvatske 14, 10000 Zagreb, Croatia; marko.petrak@pravo.hr;

ORCID ID: orcid.org/0000-0003-0920-8361 